\title{
Morphometry and DNA barcoding reveal cryptic diversity in the genus Enteromius (Cypriniformes: Cyprinidae) from the Congo basin, Africa
}

\author{
Marjolein VAN GINNEKEN ${ }^{1, \dagger}$, Eva DECRU ${ }^{2, *, \dagger}$, Erik VERHEYEN ${ }^{3} \&$ Jos SNOEKS ${ }^{4}$ \\ ${ }^{1}$ Department of Biology, Systemic Physiological and Ecotoxicological Research, \\ University of Antwerp, Groenenborgerlaan 171, 2020 Antwerpen, Belgium. \\ ${ }^{2,4}$ Royal Museum for Central Africa, Section Vertebrates, Ichthyology, \\ Leuvensesteenweg 13, 3080 Tervuren, Belgium. \\ ${ }^{2,4}$ Department of Biology, Laboratory of Biodiversity and Evolutionary Genomics, \\ KU Leuven, Charles Deberiotstraat 32, 3000 Leuven, Belgium. \\ ${ }^{3}$ Royal Belgian Institute of Natural Sciences, OD Taxonomy and Phylogeny, Vautierstraat 29, 1000 \\ Brussels, Belgium; Department of Biology, Evolutionary Ecology Group, University of Antwerpen, \\ Campus Drie Eiken, building D, room D.150 Universiteitsplein 1, 2610 Antwerpen, Belgium. \\ $\dagger$ Equally contributing authors \\ *Corresponding author: eva.decru@africamuseum.be \\ ${ }^{1}$ Email: marjolein.vanginneken@uantwerpen.be \\ ${ }^{3}$ Email: everheyen@naturalsciences.be \\ ${ }^{4}$ Email: jos.snoeks@africamuseum.be \\ ${ }^{1}$ urn:lsid:zoobank.org:author:FDADB435-8B18-49C9-B803-F925ABF21A22 \\ ${ }^{2}$ urn:1sid:zoobank.org:author:1AEB7EED-C939-4702-8590-B3FCA7076324 \\ ${ }^{3}$ urn:1sid:zoobank.org:author:86B40463-E3D9-4147-9ED3-D7302E0D64B6 \\ ${ }^{4}$ urn:1sid:zoobank.org:author:13A8AB26-FF46-437C-9806-D49E11C5E15D
}

\begin{abstract}
One of the main challenges to adequately conserve the African fish fauna is to improve our so far unsatisfactory taxonomic knowledge of important portions of the ichthyofauna. In the present study, we attempted to unravel the taxonomic diversity of some species of Enteromius Cope, 1867, a problematic African fish genus, recently collected in the north-eastern part of the Congo basin. We used an integrative approach, combining DNA barcodes and morphological analyses. For one of the species complexes found, the E. miolepis/eutaenia species complex, we evaluated taxonomic diversity over a larger geographic scale within the Congo drainage system. Although initial literature-based species identifications allowed us to assign all examined specimens to four tentative species, DNA barcodes indicated the presence of 23 distinct mitochondrial lineages. The majority of these lineages appeared endemic to particular rivers, and in most rivers multiple lineages occur in sympatry. Subsequent exploratory morphometric analyses indicated that almost all these lineages are morphologically distinguishable and that they may therefore represent undescribed species. As only a part of the Congo basin and a subset of the species diversity within Enteromius were examined, it appears that the species richness of Enteromius in the Congo basin is severely underestimated.
\end{abstract}

Keywords. 'Barbus', COI, integrative taxonomy, species richness. 
Van Ginneken M., Decru E., Verheyen E. \& Snoeks J. 2017. Morphometry and DNA barcoding reveal cryptic diversity in the genus Enteromius (Cypriniformes: Cyprinidae) from the Congo basin, Africa. European Journal of Taxonomy 310: 1-32. https://doi.org/10.5852/ejt.2017.310

\section{Introduction}

With some 3060 species in about 375 genera already described (Froese \& Pauly 2017), Cyprinidae is the largest family of freshwater fishes in the world. Within this family, the former genus Barbus sensu lato (s.1.) Cuvier \& Cloquet, 1816, was a very extensive paraphyletic aggregation of over 800 species occurring in Europe, Africa and Asia. Based on ploidy level, Barbus s.l. has been divided into three groups: diploids $(2 \mathrm{n}=48$ or 50$)$, tetraploids $(2 \mathrm{n}=100)$ and hexaploids $(2 \mathrm{n}=148-150)$ (Agnèse et al. 1990; Oellerman \& Skelton 1990; Rab et al. 1995; Berrebi \& Valiushok 1998). The phylogeny of some of these groups has been examined (e.g., Agnèse et al. 1990; Tsigenopoulos et al. 2010), and a number of studies suggested to split Barbus s.l. into several genera at least based on the level of ploidy (Berrebi et al. 1996). Due to their uncertain taxonomic position, the African small-sized diploid species were, until recently, referred to as 'Barbus' (between quotation marks) as proposed by Berrebi et al. (1996). A recent study explored the classification of the subfamily Cyprininae that includes Barbus s.1., using mitochondrial and nuclear genes (Yang et al. 2015). The results of this study supported a close relationship within the diploid species between the Asian Puntius Hamilton, 1822 species and the African small 'Barbus'. As such, they confirmed earlier results based on karyology (Golbutsov \& Krysanov 1993; Rab et al. 1995). Yang et al. (2015) proposed the revalidation of the genus Enteromius Cope, 1867 to accommodate all African diploid 'Barbus' species, as it is the oldest available genus group name for these fishes. Recently, this revalidation has been criticized (Schmidt \& Bart Jr. 2015); we prefer, however, the use of Enteromius over 'Barbus'.

The taxonomy of species of Enteromius is to date insufficiently known, resulting in difficulties in identifications and incomplete inventories of the species. It also hampers further studies on phylogenetic relationships, which are still obscure among species of Enteromius (Berrebi et al. 2014; Yang et al. 2015; Ren \& Mayden 2016). While these problems have been tackled in various Asian taxa (Berrebi \& Tsigenopoulos 2003; Pethiyagoda et al. 2012), the need for such revisions remains for the African species.

This study focuses on some species of Enteromius from the Congo basin. The Congo basin comprises the second largest catchment area in the world after the Amazon (Snoeks et al. 2011). It harbours a very high diversity of fishes with at least 957 valid species currently listed, excluding lakes Kivu and Tanganyika as well as the Malagarazi system (Froese \& Pauly 2017; Musschoot, RMCA, pers. comm.). The Congo basin is generally divided into three main sections: the Upper Congo (or Lualaba), which runs from the basin's source in Zambia down to the Wagenia Falls near the city of Kisangani in north-eastern DR Congo; the Middle Congo, which starts at the Wagenia Falls, and flows in a large arc, first northwestwards, then southwards, before widening into Pool Malebo; and the Lower Congo, which starts at the outlet of Pool Malebo and runs down to the mouth of the basin in the Atlantic Ocean (Runge 2007). Despite the fact that the Congo basin is recognized as a hotspot for fish diversity (Snoeks et al. 2011), the ichthyofauna in large parts of the basin remains poorly studied. To date, 90 morphologically often very similar species of Enteromius are recognized from the Congo basin (Vreven, RMCA, pers. comm.). Identification keys for the region are lacking and the designation of so-called species complexes is the result of the identification difficulties. One of the specific taxonomic problems within the Congolese species of Enteromius concerns the E. miolepis/eutaenia complex, which comprises species characterized by a strongly ossified first dorsal ray that is serrated along its posterior margin and a blackish mid-lateral band that extends from the tip of the snout to the caudal fin base or onto the mid-central part of the caudal fin (Tweddle \& Skelton 2008; Banyankimbona et al. 2012). Due to the similarity of the species within 
this complex (Poll 1976), the available information on morphological characteristics is often insufficient to arrive at a correct species identification. In addition, E. miolepis (Boulenger, 1902) and E. eutaenia (Boulenger, 1904) are both characterized by high intraspecific morphological variation, which suggests that these taxa could be polyspecific. Some Congolese specimens were identified as E. holotaenia (Boulenger, 1904) or E. kerstenii (Peters, 1868), although both species were described from outside the Congo basin, from the Ogowe River in Gabon and from a coastal river in Zanzibar respectively. With their ossified, serrated dorsal spine and blackish mid-lateral band, they can be considered members of the E. miolepis/eutaenia complex. Enteromius holotaenia can only be distinguished from other members of the E. miolepis/eutaenia complex by the presence of a black dorsal fin tip, which is not always clearly visible, and E. kerstenii by the presence of a red opercular spot and the absence of large scales on the dorsal fin base. However, in the Congolese specimens identified as E. kerstenii, some enlarged scales seem to be present at the dorsal fin base, although not very pronounced.

In order to unravel the taxonomy of species of Enteromius from the Congo basin and delineate the various species, a morphologic approach alone may be inadequate. The present study ascertains whether a multidisciplinary approach might facilitate the differentiation of taxa within the genus Enteromius from the Congo basin. For this, some species of the north-eastern part of the basin, a particularly poorly explored region, were selected as a case study. Additionally, because of the taxonomic problems in the E. miolepis/eutaenia complex discussed above, we have examined specimens from this complex from other regions within the Congo basin as well. We explored whether this multidisciplinary approach would result in the discovery of cryptic species, and the detection of (additional) morphological characteristics to discriminate between these species.

To attain these objectives, we used DNA barcoding (Hebert et al. 2003) together with traditional morphometrical techniques. Molecular techniques like DNA barcoding have already proven to be powerful for the identification of both marine and freshwater fish taxa (Becker et al. 2011; Pereira et al. 2013), and to detect cryptic species diversity or taxonomic inconsistencies (Goodier et al. 2011; Collins \& Cruickshank 2012; Decru et al. 2016). However, the uncritical use of molecular tools to identify species, especially using only a single molecular locus ( $\mathrm{mt}$ genome), is unwarranted (DeSalle et al. 2011), and traditional morphology has proven its value as a suitable technique to assess the diversity in many taxa. Therefore, we combined both methodologies in the present study, an approach that has already proven to be successful in several taxonomic studies (e.g., Olayemi et al. 2012; Stiassny et al. 2013; Lavoué \& Sullivan 2014).

\section{Material \& methods}

\section{Specimen selection (Fig. 2B, Table 1)}

In total, we used 181 specimens of Enteromius from the Congo Basin for morphological and/or genetic analyses. To investigate the taxonomic diversity of Enteromius in the north-eastern part of the Congo basin (Middle Congo), we examined specimens of all species of Enteromius for which tissue samples had been recently collected from rivers in this region, i.e., the Ituri, its tributary the Epulu, the Lobilo, and the Lomami/Lobaye system. To unravel the E. miolepis/eutaenia complex, we also examined specimens from various sampling sites in the Upper, Middle and Lower Congo, identified as E. miolepis, E. eutaenia, E. holotaenia or E. kerstenii. For the Middle Congo, we included specimens from the Léfini, the Itimbiri, the Ituri/Epulu, the Lobilo, and the Lomami/Lobaye. For the Upper Congo we included samples from the Loboya (a tributary of the Maiko), and the Luapula. Finally, for the Lower Congo we used samples from the rivers Luki and Inkisi. These specimens were collected during ten expeditions that were carried out between 2005 and 2012. 
Relevant types were selected based on the literature-based identifications and include the holotype of E. miolepis described from the Yembe River at Banzyville (Ubangi river system); 15 syntypes of E. holotaenia described from the Ogowe River in Gaboon; one lectotype and five paralectotypes of E. eutaenia described from Huila (Mossamedes) in Angola; the lectotype of E. kerstenii described from the coast opposite Zanzibar; the holotype of E. brazzai (Pellegrin, 1901) described from the Sangha River in Mobaka; the holotype and five paratypes of E. tshopoensis (De Vos, 1991), a junior synonym of E. brazzai, which was described from the Tshopo River; the lectotype and three paralectotypes of E. pellegrini (Poll, 1939) described from Lake Kivu; and two paratypes of E. atromaculatus (Nichols \& Griscom, 1917) described from the Yakuluku River (Lévêque \& Daget 1984) (see also Appendix 1).

We attempted to use the same specimens for the morphological and genetic analyses, but this was not always possible. As some specimens were lost or too damaged, 40 specimens that were genetically examined could not be used for morphological analyses. In 19 of these cases, literature-based identifications could not even be done, and the specimens were identified as Enteromius sp. As such, we morphologically examined 177 specimens (Table 1, Appendix 1), including several type specimens. Similarly, not all specimens that we examined morphologically could be successfully DNA barcoded, and genetic samples are unavailable for the type specimens.

\section{Morphological analyses}

\section{Specimen identifications}

Based on published characteristics, we assigned the non-type specimens to four 'a priori' groups: 60 to E. cf. miolepis (which represents the E. miolepis/eutaenia complex); 15 to E. cf. brazzai; 26 to E. cf. pellegrini; and 40 to $E$. cf. atromaculatus. We used 'cf.' to indicate the uncertainty connected to their identifications. The four groups mainly differ in the morphology of their dorsal spine (ossified or flexible; serrated or not) and colour pattern (Fig. 1). Enteromius cf. miolepis has an ossified serrated dorsal spine and a mid-lateral band on the flank and through the eye; $E$. cf. brazzai has a flexible unserrated dorsal spine and no melanin markings; E. cf. pellegrini has an ossified serrated dorsal spine and large dark

A
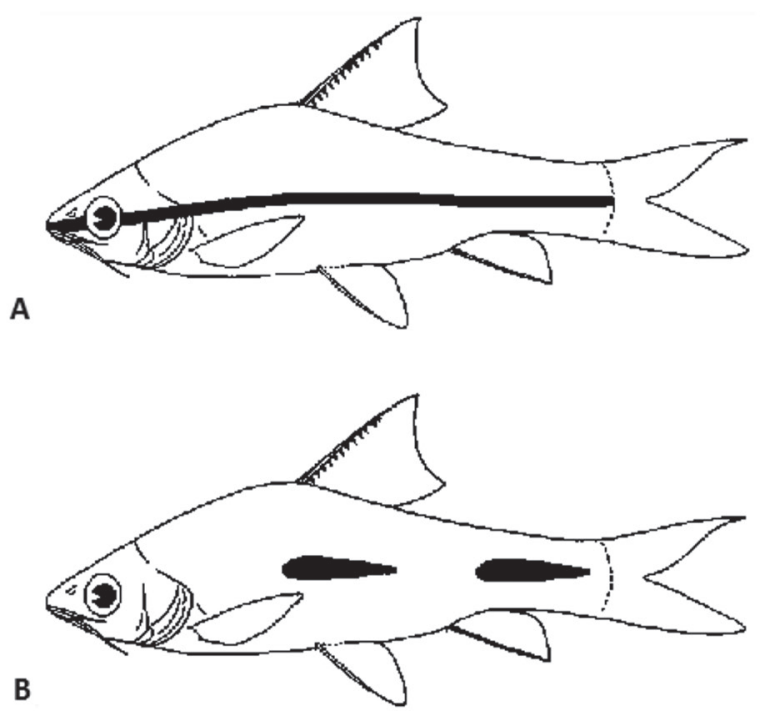

C

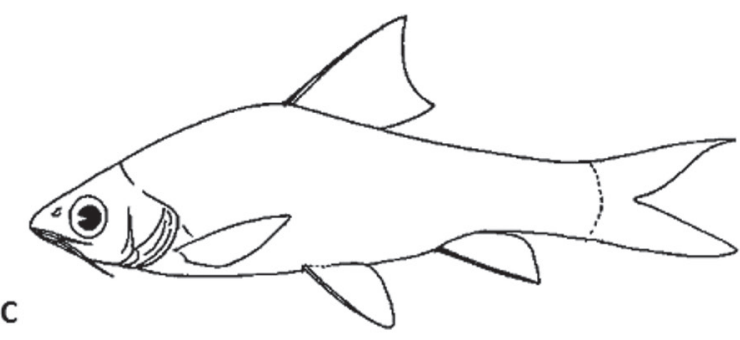

D

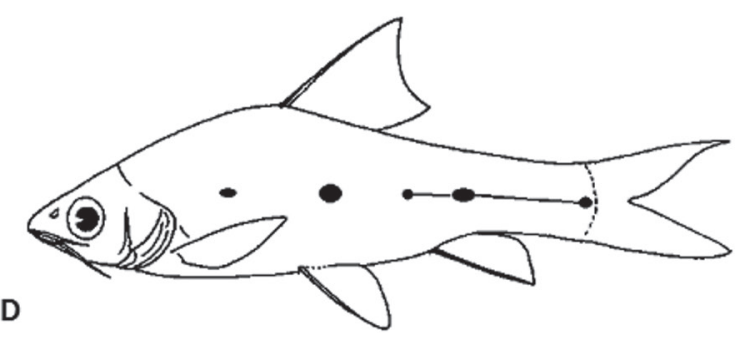

Fig. 1. Schematic representation of the four 'a priori' Enteromius groups with their characteristic morphological features (dorsal spine morphology and melanin pattern). A. E. cf. miolepis (Boulenger, 1902) (38.1-111.0 mm). B. E. cf. pellegrini (Poll, 1939) (40.7-81.3 mm). C. E. cf. brazzai (Pellegrin, 1901) (44.8-82.8 mm). D. E. cf. atromaculatus (Nichols \& Griscom, 1917) (28.3-55.8 mm). Drawings modified from Bamba et al. (2011). 
Table 1. Number of examined non-type specimens of Enteromius Cope, 1867 per river (system) studied. A. Specimens other than those belonging to the E. miolepis/eutaniea complex. B. Specimens belonging to the E. miolepis/eutaenia complex. Numbers represent morphometrically analysed specimens vs genetic samples, then the number of specimens analysed morphologically as well as genetically.

\begin{tabular}{lccc}
\hline A & River & $\begin{array}{c}\text { Spec. examined } \\
\text { (morphological/ } \\
\text { genetical) }\end{array}$ & $\begin{array}{c}\text { Spec. examined } \\
\text { morphological \& genetical }\end{array}$ \\
\hline Middle Congo & Ituri & $36 / 28$ & 16 \\
& Epulu (tributary Ituri) & $32 / 7$ & 7 \\
& Lobilo & $10 / 11$ & 10 \\
\hline \multirow{3}{*}{ B } & Lobaye (tributary Lomami) & $3 / 3$ & 3 \\
\hline Upper Congo & & & \\
& Loboya (tributary Maiko) & $0 / 1$ & 6 \\
\hline Middle Congo & Léfini & $5 / 5$ & 5 \\
& Itimbiri & $2 / 2$ & 2 \\
& Ituri & $6 / 13$ & 4 \\
& Epulu (tributary Ituri) & $19 / 7$ & 5 \\
& Lobilo & $4 / 7$ & 4 \\
& Lomami & $1 / 1$ & 1 \\
& Lobaye (tributary Lomami) & $4 / 4$ & 3 \\
\hline Lower Congo & Inkisi & $3 / 8$ & 3 \\
& Luki & $10 / 10$ & 5 \\
\hline
\end{tabular}

spots that can fuse into a mid-lateral band; and $E$. cf. atromaculatus has a flexible unserrated dorsal spine and small spots that can fuse into a mid-lateral band.

\section{Morphometry}

For the 177 examined specimens, we obtained 17 measurements with a vernier caliper (Helios, $0.05 \mathrm{~mm}$ ), as well as 10 meristics. Counts and measurements were based on Bamba et al. (2011), with some small modifications: the pre-occipital distance, post-dorsal distance I, post-anal distance I, and body-depth I were not included; the standard length, post-dorsal distance II, and post-anal distance II were measured up to the insertion of the first caudal fin ray of the upper lobe instead of to the middle of the caudal peduncle base. Barbel lengths were also coded according to Bamba et al. (2011). Head measurements were expressed as percentages of head length (HL) and body measurements as percentages of standard length (SL).

Abbreviations of the measurements and counts:
AFR $=$ Anal fin rays
$\mathrm{BD} \quad=$ Body depth
$\mathrm{CPSc}=$ Caudal peduncle scales
DFR $=$ Dorsal fin rays
D-L Sc $=$ Scales dorsal fin-lateral line 


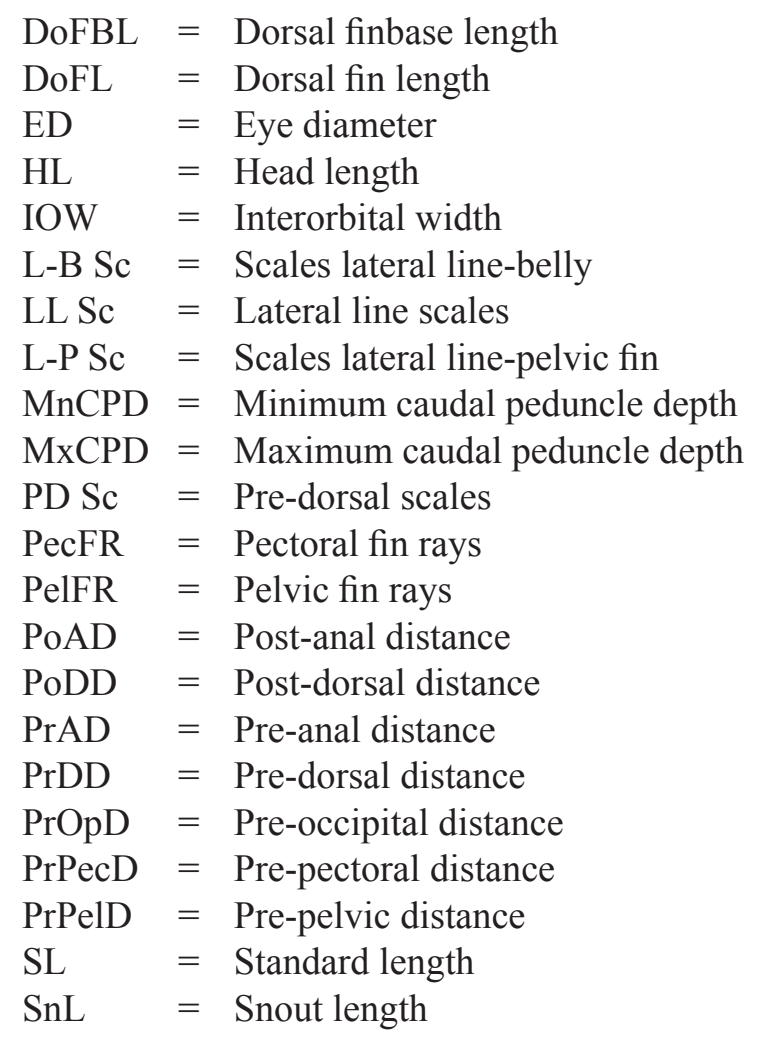

\section{Data analyses}

We used principal component analysis to explore the multivariate data matrix and to reduce the large number of variables into a few meaningful axes (Snoeks 2004; Decru et al. 2012). PCAs were executed in Past 3.15c (Hammer et al. 2001). Raw data were used for meristics, log-transformations for the measurements. By using log-transformations, the first component can be interpreted as a proxy for size, since it is characterized by loadings with the same sign and same order of magnitude for all variables (Bookstein et al. 1985). Because the barbel lengths were coded (Bamba et al. 2011) as categorical variables, they were not included in the PCAs. PC loadings of the illustrated PCAs are given in the Appendices 2-8.

\section{Genetic analyses}

\section{DNA Extraction, PCR amplification and sequencing}

We successfully barcoded 114 specimens using DNA extracted from finclips (Table 1). The method used is based on the FISH-BOL (Fish Barcode of Life) protocol (Steinke \& Hanner 2011). DNA was extracted using a 'NucleoSpin ${ }^{\circledR}$ Tissue Kit' following the instructions of the manufacturer (Macherey-Nagel, Germany). Subsequently, polymerase chain reactions (PCR) were used to amplify the mitochondrial cytochrome $c$ oxidase I (COI) gene. A part of the samples was amplified with 'Fish Cocktail', an M13 tailed primer combination (Ivanova et al. 2007) (Table 2). A standard $25 \mu \mathrm{L}$ PCR mix consisted of $2.5 \mu \mathrm{L}$ PCR buffer (10x); $2.5 \mu \mathrm{L}$ dNTP $(2 \mathrm{mM}) ; 1.25 \mu \mathrm{L}$ 'Fish Cocktail' $(2 \mu \mathrm{M}) ; 0.2$ Taq DNA Polymerase ( 5 units per $\mu \mathrm{L}$ ); $16.75 \mu \mathrm{L} \mathrm{mQ-H} 2 \mathrm{O}$ and $2.0 \mu \mathrm{L}$ of the extracted DNA sample. The PCR profile was 3 min at $94^{\circ} \mathrm{C}$, followed by 35 cycles of $40 \mathrm{~s}$ at $94^{\circ} \mathrm{C}, 40 \mathrm{~s}$ at $52^{\circ} \mathrm{C}$, and $1 \mathrm{~min}$ at $72^{\circ} \mathrm{C}$, plus a final extension of $10 \mathrm{~min}$ at $72^{\circ} \mathrm{C}$. The success rate of this PCR-mix was relatively low, which led to the development of specific primers, Bbus $\mathrm{F}$ and Bbus R, for the amplification of samples that weren't successfully sequenced with 'Fish Cocktail' (Table 2). In this PCR mix, instead of 'Fish Cocktail', $2.5 \mu \mathrm{L}$ of each specific primer was used, and an annealing temperature of $54^{\circ} \mathrm{C}$ instead of $52^{\circ} \mathrm{C}$. Amplified products were verified on $1.2 \%$ agarose gels. Afterwards the PCR products were purified using a Nucleofast ${ }^{\circledR}$ 
Table 2. Sequences 5' -3 ' of the primers used for the PCR reactions.

\begin{tabular}{ll}
\hline Name & Cocktail name / Primer sequence 5'-3' \\
\hline & 'Fish cocktail' (M13-tail): C_FishF1t1-C_FishR1t1 (ratio 1:1:1:1) \\
VF2_t1 & TGTAAAACGACGGCCAGTCAACCAACCACAAAGACATTGGCAC \\
FishF2_t1 & TGTAAAACGACGGCCAGTCGACTAATCATAAAGATATCGGCAC \\
FishR2_t1 & CAGGAAACAGCTATGACACTTCAGGGTGACCGAAGAATCAGAA \\
FR1d_t1 & CAGGAAACAGCTATGACACCTCAGGGTGTCCGAARAAYCARAA \\
Reference: & Ivanova et al. (2007) \\
\hline & Primer sequences for M13-tails \\
M13F & TGTAAAACGACGGCCAGT \\
M13R & CAGGAAACAGCTATGAC \\
Reference: & Messing (1983) \\
\hline & Primer sequences for Enteromius specific primers \\
Bbus F & TGAGCCGGAATAGTGGGAAC \\
Bbus R & CCTGCRGGGTCRAAGAATGT \\
\hline
\end{tabular}

96 PCR kit (Macherey-Nagel, Germany), and sequenced bidirectionally using BigDye Terminator v.3.1 and an ABI 3130 capillary sequencer.

\section{DNA analyses}

The DNA sequences were assembled and visually checked in CodonCode Aligner 5.1.4 (CodonCode Corporation) and aligned in MEGA 5.2 using Muscle Alignment (Edgar 2004; Tamura et al. 2011). The longer M13-sequences were shortened to the length of the Bbus-sequences (558 bp). Next, MEGA 5.2 was used to execute a model test and to create a phylogenetic tree. The model test indicated the $\mathrm{GTR}+\mathrm{G}+\mathrm{I}$ as the optimal model using the AIC criterion. This model was used to construct a MaximumLikelihood (ML) tree with 1000 bootstrap replications. As both the ML tree and NJ (Neighbour Joining) tree gave similar results, statistical node support of both methods are visualised on the ML tree.

\section{Results}

Class Actinopterygii Klein, 1885

Subclass Neopterygii Regan, 1923

Division Teleostei Müller, 1846

Order Cypriniformes Rafinesque, 1810

Family Cyprinidae Rafinesque 1815

Genus Enteromius Cope, 1867

\section{Evaluation of the literature-based identifications}

In the ML tree obtained (Fig. 2), lineages with less than 2\% sequence divergence were collapsed and named after the river system from which the specimens were collected. Specimens from the Lomami/ Lobaye system and the Lobilo were grouped under the label 'Kisangani region', since there appeared to be little or no genetic difference between samples of these nearby affluents.

The ML tree shows 23 lineages within the assayed Enteromius samples, representing the four 'a priori' morphospecies in the following quantities/properties: 13 of which belong to the E. cf. miolepis group; three to the E. cf. brazzai group; one to the E. cf. pellegrini group; and six to the E. cf. atromaculatus 


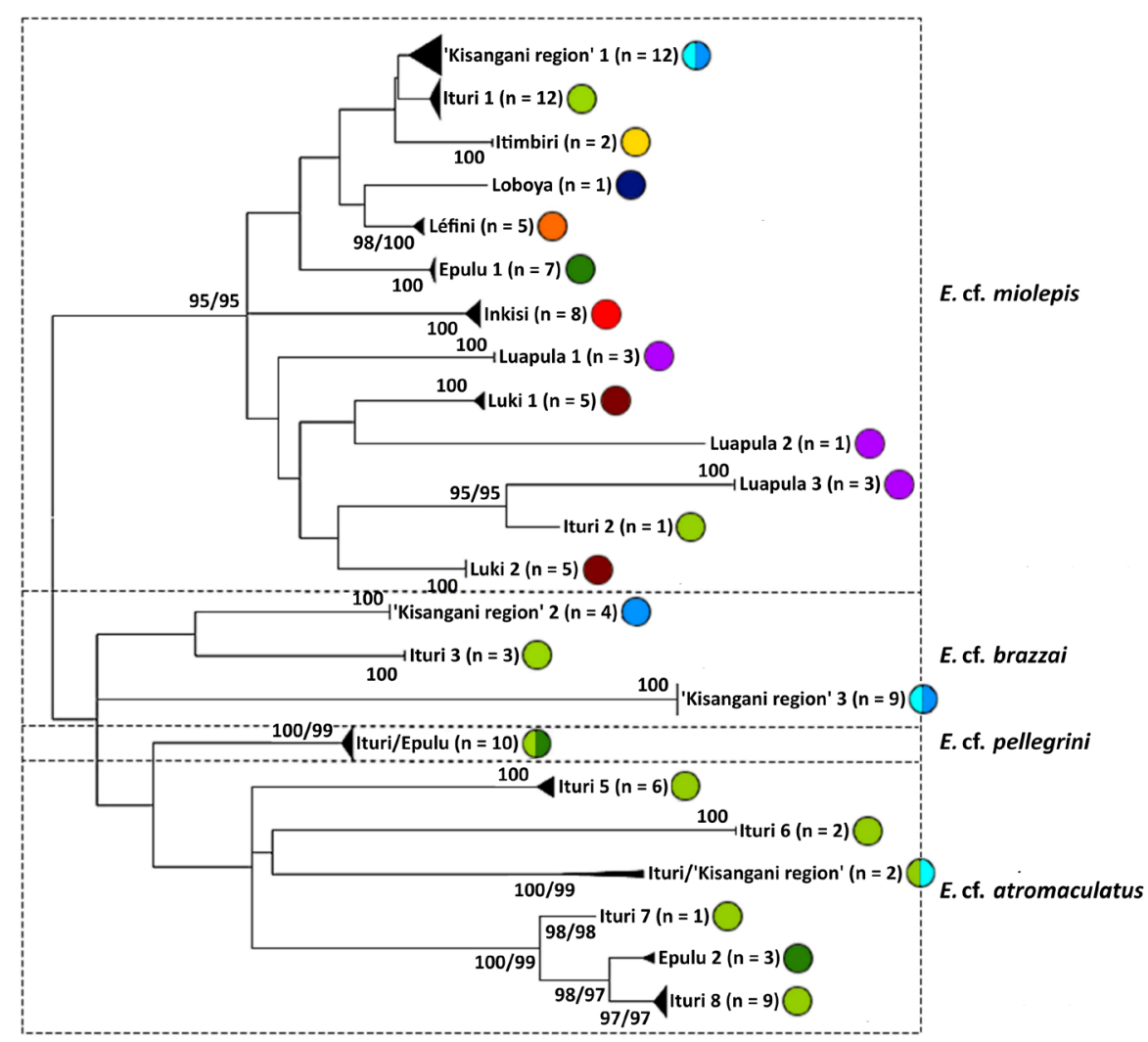

A
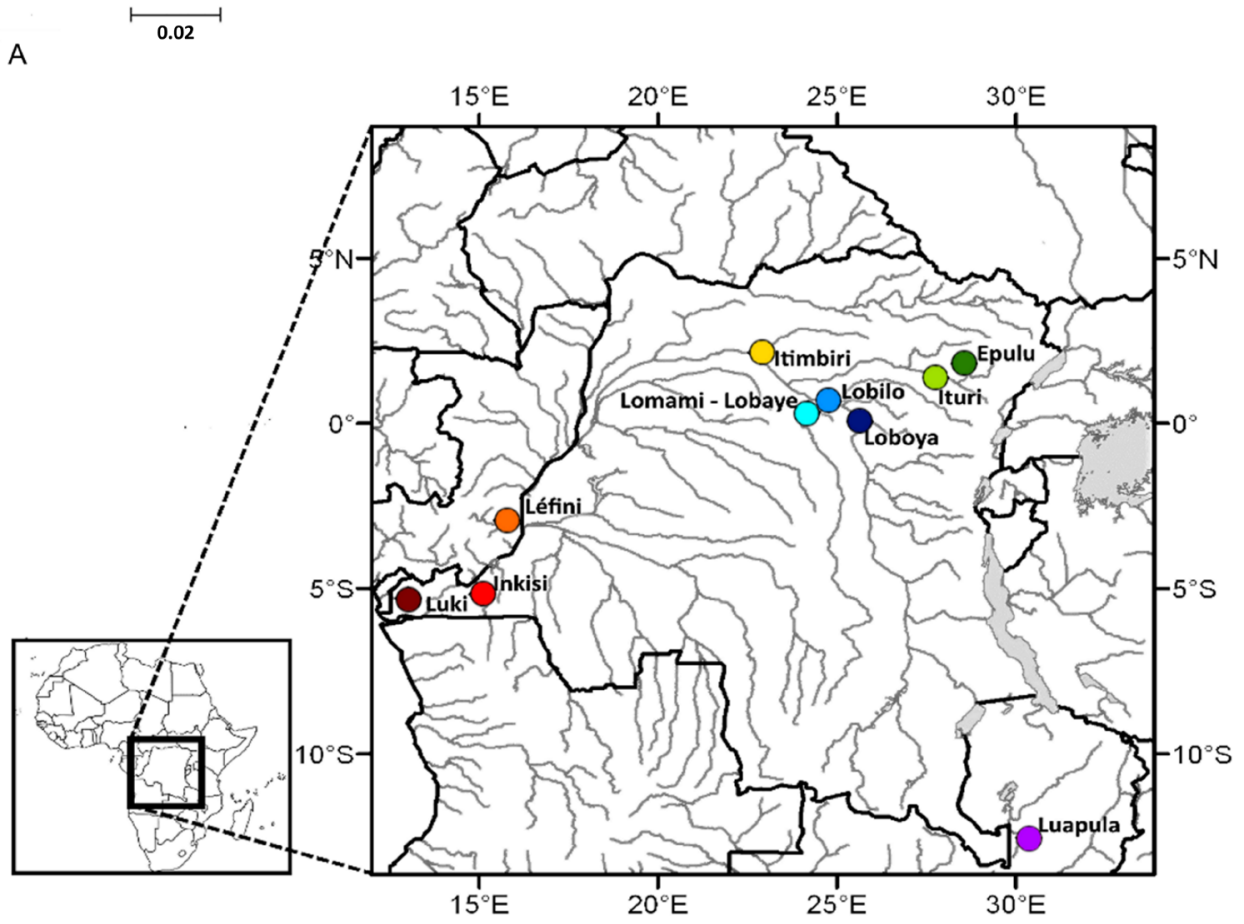

B

Fig. 2. A. ML tree based on 558-bp-long Enteromius COI sequences with 1000 bootstrap replications, with node support shown as NJ/ML bootstrap (bootstrap values $>95 \%$ are shown; lineages $<2 \%$ sequence divergence were collapsed), the label 'Kisangani region' contains samples from the Lomami/ Lobaye system and the Lobilo. B. Map of the Congo basin with the sampled river stretches indicated according to the phylogenetic lineages. 
group. Enteromius cf. miolepis, E. cf. atromaculatus and E. cf. pellegrini each form clearly supported clades, while this is not the case for $E$. cf. brazzai. There is often a substantial genetic distance between lineages occurring in different rivers, but also between some lineages detected in the same river. For example, within the E. cf. miolepis group, we observed a considerable difference between specimens of the Luapula (three lineages; $14.6 \%$ sequence divergence between Luapula 1 and 2; $15.3 \%$ between Luapula 1 and $3 ; 19.0 \%$ between Luapula 2 and 3 ), and the Luki (two lineages; $7.7 \%$ sequence divergence). Interestingly, the sequences obtained for the Upper, Middle and Lower Congo populations did not group according to these zoogeographic regions. However, two out of the three lineages of the Luapula, a river system geographically remote from the other rivers included in this study, also show the largest genetic distances within the E. cf. miolepis clade. Enteromius cf. brazzai is not resolved as a single clade, and consists of three lineages, two of which were detected in the 'Kisangani region' (19.8\% sequence divergence). In contrast to the other groups, E. cf. pellegrini consists of a single lineage that is composed of specimens from a single river, the Ituri. The $E$. cf. atromaculatus group contains an important amount of genetic variation, with five of its six lineages occurring in the Ituri River. Remarkably, one of those lineages also contains one sample from the 'Kisangani region'.

\section{Morphometric groupings}

Firstly, PCAs were executed on all the specimens examined, after which more detailed PCAs were performed on each literature-based 'a priori' group separately.

\section{Overall analyses}

The highest loadings on PC2 for a PCA on 17 log-transformed measurements $(\mathrm{n}=177)$ are for the eye diameter (ED), the post-anal distance (PoAD) and the dorsal fin length (DoFL); PC1 is a proxy for size (see above). On a scatterplot of PC2 against PC1, the four 'a priori' groups cannot all be distinguished from each other (Fig. 3). However, specimens of E. cf. pellegrini and E. cf. brazzai are completely separated from each other on PC2. This is mainly because $E$. cf. pellegrini has a smaller ED, a smaller dorsal fin base length (DoFBL) and a smaller PoAD than E. cf. brazzai. Clearly E. cf. miolepis occupies the largest morphospace on PC2, which comprises most of the type specimens included, except for two paralectotypes of E. eutaenia and one syntype of $E$. holotaenia. The E. cf. atromaculatus polygon comprises the paratypes of $E$. atromaculatus. The specimens of $E$. cf. pellegrini, however, only overlap slightly with the type specimens of E. pellegrini and the specimens of $E$. cf. brazzai are separated from the holotype of E. brazzai and types of E. tshopoensis. Furthermore, the type specimens of E. tshopoensis are separated from the other groups, mainly on PC2, due to a smaller PoAD and a larger DoFL.

The highest loadings on PC1 for a PCA on 10 meristics $(n=177)$ are for the number of scales between the lateral line and the belly (L-B Sc), the number of scales between the dorsal fin and the lateral line (D-L Sc) and the number of scales between the lateral line and the pelvic fin (L-P Sc); on PC2 for the number of scales on the lateral line (LL Sc), the number of scales between the occiput and the base of the first dorsal fin ray (PD Sc) and the number of pelvic fin rays (PelFR). Similar to the analysis for the measurements, a scatterplot of PC2 against PC1 does not allow the separation of the four 'a priori' groups (Fig. 4). Again, E. cf. miolepis is the group showing the largest variation. Also, E. cf. pellegrini and $E$. cf. brazzai are again completely separated on PC1, mainly due to $E$. cf. pellegrini having a higher D-L Sc (4.5-5.5 vs 3.5) and a higher L-B Sc (5-6 vs 4-5). Furthermore, the four 'a priori' groups all overlap with their respective type specimens.

To examine whether morphological differences could be detected between the different genetic lineages within each group, we performed PCAs on E. cf. miolepis, E. cf. brazzai and E. cf. atromaculatus separately. To investigate whether one or more lineages represent a currently valid species, relevant type 
specimens were also included in these analyses. This resulted in a multitude of analyses for which the most important outcomes are presented below.

\section{Morphometric comparisons among $\boldsymbol{E}$. cf. miolepis lineages}

Because of the high number of lineages and specimens for $E$. cf. miolepis, we analysed the major geographical regions, the Upper, the Middle and the Lower Congo, separately (see also Table 1), but still included the relevant type specimens to check whether some groups could be allocated to these species. Only the results of the latter are discussed as an example.

For the Lower Congo, we detected three genetic lineages within E. cf. miolepis (Fig. 2), i.e., one group containing specimens from the Inkisi and two groups with specimens from the Luki (Luki 1 and Luki 2). The highest loadings on PC1 for a PCA on 10 meristics $(n=36)$ are for LL Sc, CP Sc and PecFR; on PC2 again for PecFR, AFR and PD Sc. The specimens from the Inkisi are well separated from the Luki lineages on both PC1 and PC2; and there is only one specimen overlap between Luki 1 and Luki 2 (Fig. 5). In addition, specimens from these latter two lineages noticeably differ in the length of their barbels. Lineages Inkisi and Luki 1 can be clearly distinguished from all type specimens (Fig. 5). Luki 2 overlaps with the type specimens of E. eutaenia and E. holotaenia, but Luki 2 differs from the E. eutaenia types in barbel length. A PCA of the log-transformed measurements did not separate the genetic lineages from each other or from the type specimens (not illustrated).

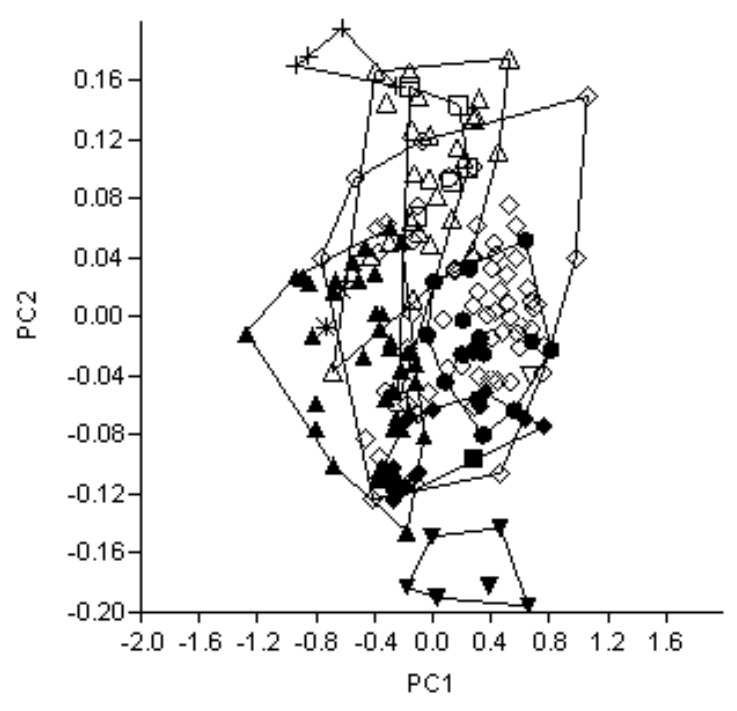

Fig. 3. Scatterplot of PC2 against PC1 for a PCA on 17 log-transformed measurements $(n=177)$ of Enteromius Cope, 1867: E. cf. miolepis (Boulenger, 1902) (৩), E. cf. brazzai (Pellegrin, 1901) (४), E. cf. pellegrini (Poll, 1939) ( $\Delta$ ), and E. cf. atromaculatus (Nichols \& Griscom, 1917) (A). Also shown are the type specimens examined of: E. miolepis (Boulenger, 1902) (O), E. holotaenia (Boulenger, 1904) $(\bullet)$, E. eutaenia (Boulenger, 1904) (口), E. kerstenii (Peters, 1868) (•), E. brazzai (Pellegrin, 1901) ( $\nabla)$, E. tshopoensis (De Vos, 1991) ( $\mathbf{\nabla})$, E. pellegrini (Poll, 1939) (+), and E. atromaculatus (Nichols \& Griscom, 1917) (*). 
For the Middle Congo and Upper Congo, we detected respectively six and four genetic lineages of $E$. cf. miolepis (Fig. 2). Similar exploratory morphometric analyses of these genetic lineages, as for the Lower Congo discussed above, indicated that almost all could be separated from each other as well as from the included type specimens. However, specimens from 'Kisangani region' 1, Itimbiri and the syntypes of $E$. holotaenia clustered on the PCAs. Yet, the Itimbiri specimens had a different colour pattern (a black anal fin tip), which is absent in the 'Kisangani region' 1 specimens as well as in the syntypes of E. holotaenia.

When comparing all lineages of E. cf. miolepis (Lower, Middle and Upper Congo), each could be morphologically distinguished from the others based on meristics (Fig. 6), measurements and/or barbel length (not illustrated). Only specimens from Kisangani region' 1 and Itimbiri could not be separated from each other, but differed in colour pattern (see above).

\section{Morphometric comparisons among $E$. cf. brazzai lineages}

We observed three genetic lineages within E. cf. brazzai (Fig. 2). The highest loadings on PC1 for a PCA on 10 meristics $(\mathrm{n}=22)$ are for LL Sc, PecFR and PelFR; on PC2 for CP Sc, L-B Sc and again PecFR. Specimens from the 'Kisangani region' 2 are well separated from the Ituri 3 lineage on PC2 and both genetic lineages differ from the 'Kisangani region' 3 lineage and type specimens on PC1 (Fig. 7). The polygon of specimens from the 'Kisangani region' 3 lineage comprises the holotype of E. brazzai and overlaps with the types of $E$. tshopoensis. However, the eight specimens from the 'Kisangani region' 3

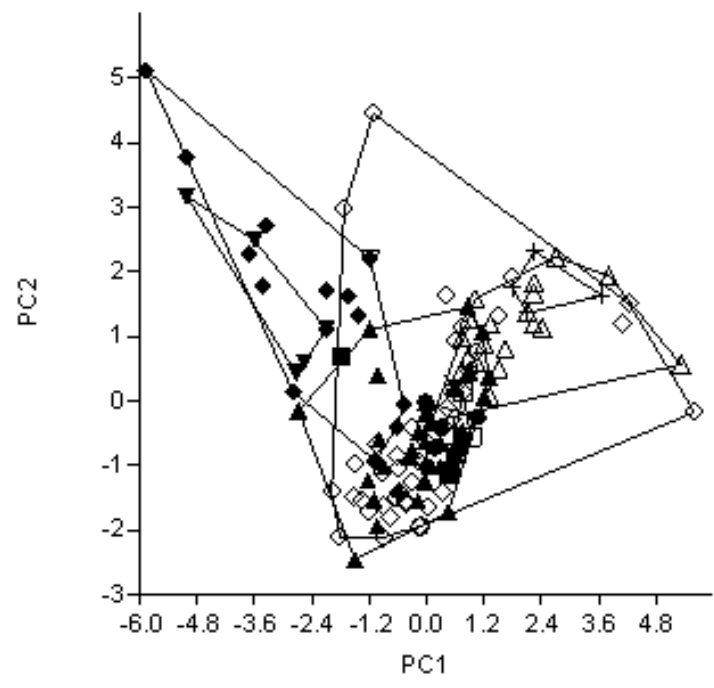

Fig. 4. Scatterplot of $\mathrm{PC} 2$ against $\mathrm{PC} 1$ for a PCA on 10 meristics $(\mathrm{n}=177)$ of Enteromius: E. cf. miolepis (Boulenger, 1902) ( $\diamond)$, E. cf. brazzai (Pellegrin, 1901) ( $\diamond)$,E. cf. pellegrini (Poll, 1939) ( $\Delta$ ), and E. cf. atromaculatus (Nichols \& Griscom, 1917) ( $\mathbf{\Delta})$. Also shown are the type specimens examined of: E. miolepis (Boulenger, 1902) (०), E. holotaenia (Boulenger, 1904) (•), E. eutaenia (Boulenger, 1904) $(\square)$, E. kerstenii (Peters, 1868) (ロ), E. brazzai (Pellegrin, 1901) ( $\nabla)$, E. tshopoensis (De Vos, 1991) ( $\mathbf{\nabla})$, E. pellegrini (Poll, 1939) (+), and E. atromaculatus (Nichols \& Griscom, 1917) (*). 
lineage as well as the holotype of E. brazzai differ from the types of E. tshopoensis by the absence of barbels.

\section{Morphometric comparisons among $E$. cf. atromaculatus lineages}

We detected six genetic lineages within E. cf. atromaculatus (Fig. 2). Although there was only $1.75 \%$ sequence divergence between the lineages of Epulu 2 and Ituri 8, we interpreted these lineages as separate Operational Taxonomic Units (OTUs, i.e., clusters of similar DNA sequences) because of the observed differences in colour pattern (specimens from the Epulu 2 lineage have mid-lateral dots, while specimens from Ituri 8 display a vague mid-lateral band). The single specimen from Ituri 7 was lost and could not be measured. The highest loadings on PC1 for a PCA of 10 meristics $(n=42)$ are for LL Sc, PecFR and D-L Sc; on PC2 for CP Sc, again PecFR and D-L Sc. A plot of PC2 vs PC1, separates the two specimens from the Ituri 6 lineage from all other lineages based on PC2 (Fig. 8). The specimens from the Ituri/'Kisangani region' lineage are separated from all other lineages mainly on PC1. The Ituri 5 lineage is separated from the Ituri 6 and Epulu 2 lineages along PC2, from the E. atromaculatus type specimens on PC1, and from the Ituri/'Kisangani region' and Ituri 8 lineages on a combination of PC1 and PC2.

As the initial PCA resulted in a great overlap between the Epulu 2 and Ituri 8 lineages, we carried out a second PCA on 10 meristics, only including specimens from these lineages and the types of E. atromaculatus. The highest loadings on PC1 are for LL Sc, D-L Sc and CP Sc; on PC2 for PecFR, PD Sc and the number of pelvic fin rays (PelFR). On a plot of PC2 versus PC1, specimens from Epulu 2 and Ituri 8 still overlap and the types of E. atromaculatus overlap with specimens from Epulu 2 (Fig. 9). These groups also overlap on a PCA of 17 log-transformed measurements (not illustrated).

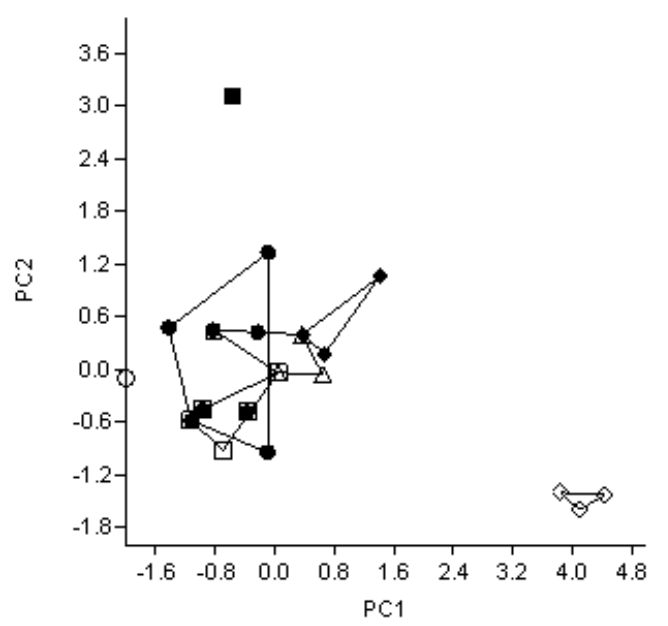

Fig. 5. Scatterplot of $\mathrm{PC} 2$ against $\mathrm{PC} 1$ for a PCA on 10 meristics $(\mathrm{n}=36)$ of $E$. cf. miolepis specimens from the Lower Congo: Inkisi $(\diamond)$, Luki $1(\diamond)$ and Luki $2(\Delta)$. Also shown are the type specimens examined of: E. miolepis (Boulenger, 1902) (०), E. holotaenia (Boulenger, 1904) (•), E. eutaenia (Boulenger, 1904) ( $\square$ ) and E. kerstenii (Peters, 1868) (ロ). 


\section{Discussion}

\section{Multidisciplinary approach to detect cryptic species}

Specimens from the genus Enteromius are notoriously difficult to identify. As, apart from some regional reviews (e.g., Bamba 2012), no extensive continent-wide reviews have been carried out for this genus, the available literature for species identifications is often limited to the accounts of the original species descriptions. Recent molecular studies already revealed Enteromius to be non-monophyletic (Yang et al. 2015; Ren \& Mayden 2016).

Our study examined whether a multidisciplinary approach could provide more insight into the taxonomy of some species of Enteromius from the Congo basin and whether it might reveal cryptic diversity. For the examined species in this study, a literature-based identification led to the delineation of four so-called 'a priori' species. The reliability of these 'a priori' identifications was tested using a combined approach that consisted of DNA barcoding and a detailed morphometric approach that allowed the comparison of the specimens from our collection with relevant type specimens.

This approach revealed a high number of potentially new species of Enteromius within the examined samples/specimens. DNA barcoding uncovered the existence of 23 genetic lineages within the four 'a priori' species obtained by literature-based identifications. The genetic distances between many of the lineages, even within the 'a priori' species, were substantial. Sometimes they even reached almost $20 \%$, which is considerably larger compared to most other African freshwater fish taxa, that usually have

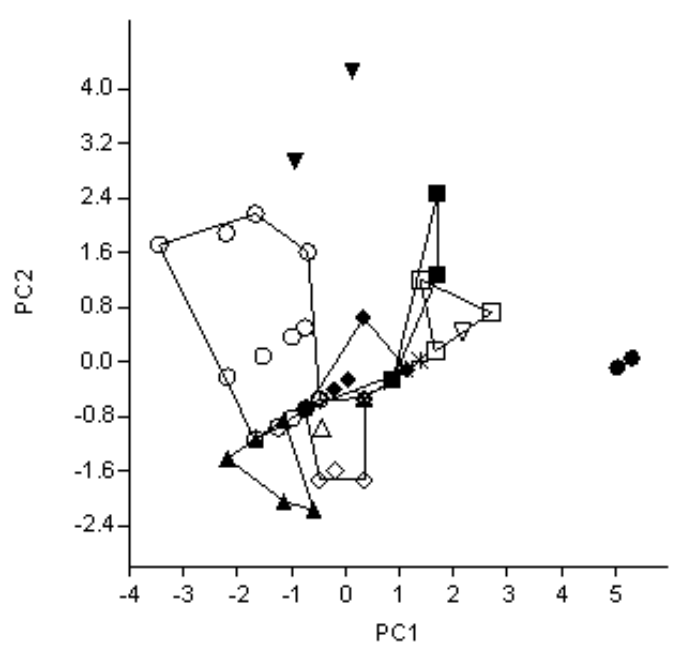

Fig. 6. Scatterplot of $\mathrm{PC} 2$ against $\mathrm{PC} 1$ for a PCA on 8 meristics $(\mathrm{n}=60)$ of $E$. cf. miolepis (Boulenger, 1902) specimens from the Congo basin (excluding types): 'Kisangani region' $1(\diamond)$ ), Ituri $1(\diamond)$, Itimbiri $(\Delta)$, Léfini $(\boldsymbol{\Delta})$, Epulu $1(\circ)$, Inkisi $(\bullet)$, Luapula $1(\square)$, Luki $1(\bullet)$, Luapula $2(\nabla)$, Luapula $3(\boldsymbol{\nabla})$, Ituri $2(+)$, and Luki $2(*)$. Specimens from Luapula 1 and Luapula 2 can be separated from each other based on a PCA on the log-transformed measurements; specimens of Luki 2 fall separated when barbel lengths are included; specimens from Kisangani region' 1 and Itimbiri can be distinguished based on colour pattern. 
interspecific divergences lower than or around $10 \%$ for the COI gene (see, e.g., Lowenstein et al. 2011; Decru et al. 2016). Only three of the four 'a priori' species agreed with supported clades in our ML tree, i.e., E. cf. miolepis, E. cf. pellegrini and E. cf. atromaculatus, while the lineages of $E$. cf. brazzai do not form a supported clade. Subsequent exploratory morphometric analyses revealed that, despite the small sample sizes, most lineages could be separated on the basis of their morphology. The fact that specimens from separate genetic lineages are morphologically distinguishable, suggests that they may represent different species. Therefore, our hypothesis that at least the E. miolepis/eutaenia complex represents a polyspecific complex appears to be confirmed by our results, as within $E$. cf. miolepis we detected no less than 13 putative species. Also in the ML tree of Ren \& Mayden (2016), samples from the E. miolepis/ eutaenia complex formed five distinct lineages, three identified as E. kerstenii, one as E. miolepis, and one as E. holotaenia. Furthermore, respectively three and six putative species were detected in the 'a priori' species $E$. cf. brazzai and E. cf. atromaculatus. Interestingly, one of the important differences between the $E$. cf. brazzai lineages was the number of branched pelvic fin rays ( $7 \mathrm{vs} 8$ ). As far as we are aware, variation in the number of pelvic fin rays is uncommon in Enteromius. Enteromius cf. pellegrini is the only 'a priori' species that appears to be monospecific within the study area.

Providing formal descriptions with diagnoses of the undescribed species of Enteromius lies outside the scope of the present study, as it requires a detailed morphological examination of more specimens of each OTU and from other areas to unequivocally delineate species-specific diagnostic characteristics. In some analyses, type specimens ended up within or very close to the polygon of a particular OTU: the types of E. holotaenia partially overlapped with two OTUs of E. cf. miolepis, i.e., Luki 2 and 'Kisangani region' 1; the holotype of E. brazzai fell within an OTU of E. cf. brazzai from the Kisangani region ('Kisangani region' 3); and the types of E. atromaculatus overlapped with an OTU of E. cf. atromaculatus from the Epulu (Epulu 2). However, this does not necessarily imply that the OTUs are conspecific with the respective types. Our results indicated that in almost every studied river stretch at least one distinct species of Enteromius occurs, which makes it very unlikely that one of our studied OTUs from the Congo basin indeed represents E. holotaenia, a species originally described from the Ogowe River in the Lower Guinea ichthyofaunal province. Most of the specimens examined lacked the

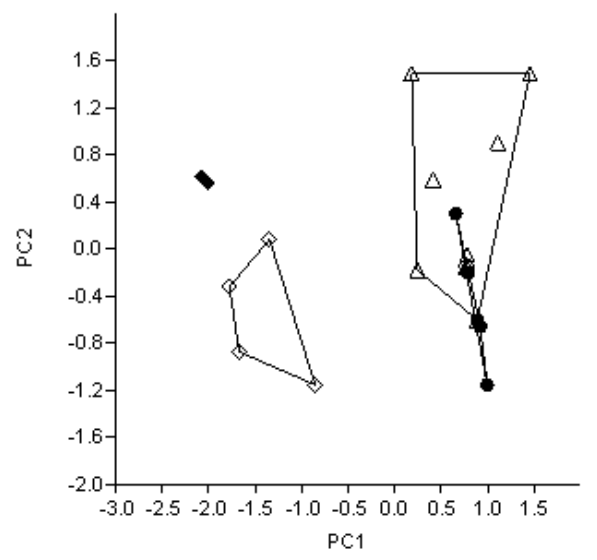

Fig. 7. Scatterplot of PC2 against $\mathrm{PC} 1$ for a PCA on 10 meristics $(\mathrm{n}=22)$ of $E$. cf. brazzai (Pellegrin, 1901): 'Kisangani region' $2(\diamond)$, Ituri $3(\diamond)$ and 'Kisangani region' $3(\Delta)$. Also shown are the type specimens examined of E. brazzai (Pellegrin, 1901) (०) and E. tshopoensis (De Vos, 1991) (•). 
black dorsal tip present in E. holotaenia. However, it was present in most of the specimens from Luki 2 , in two of the nine specimens examined from 'Kisangani region 1', in both specimens from Itimbiri 1 and in one of the five specimens from the Léfini. This demonstrates that this feature is not consistently present in the lineages. Hence, it does not seem a good criterion for species to distinguish these taxa, also because this characteristic is paraphyletic in the ML tree (Fig. 2).

For E. atromaculatus and E. brazzai the situation appears to be different. Enteromius atromaculatus is described from the Yakuluku River (Uele River), which is in the vicinity of the Epulu River; and Enteromius brazzai is described from the Sangha River, which is also part of the Middle Congo. It is therefore plausible that the Epulu 2 population is conspecific with E. atromaculatus, and that 'Kisangani region' 3 is conspecific with E. brazzai. This implies that at least 21 of our 23 OTUs may represent new species that will need to be formally described in the future.

\section{Distribution patterns and speciation processes}

All species to which the specimens were originally assigned are presumed to have large distribution ranges that, except for E. atromaculatus, extend beyond the Congo basin. These wide distribution ranges of the four 'a priori' species on the one hand, and the often much narrower distribution ranges of the putative new species detected through DNA barcoding on the other, may be a reason why up to now, these OTUs were not detected as different species. Indeed, as the majority of earlier studies on ichthyofaunal diversity concern collections from small areas and even individual rivers, the studied specimens are often identified as one of the morphologically similar species presumed to occur in the studied region. Unfortunately, these identifications rarely imply detailed comparisons with specimens from other regions, let alone type specimens. In our study, most of the sympatric lineages were morphologically clearly distinct, and were as such already assigned to different 'a priori' species. In addition, the allopatric lineages within each of these 'a priori' species were morphologically sufficiently similar to remain grouped for as long as they were not subjected to comparisons based on multivariate morphometric methods. Although minor morphological differences can be interpreted as intraspecific geographic

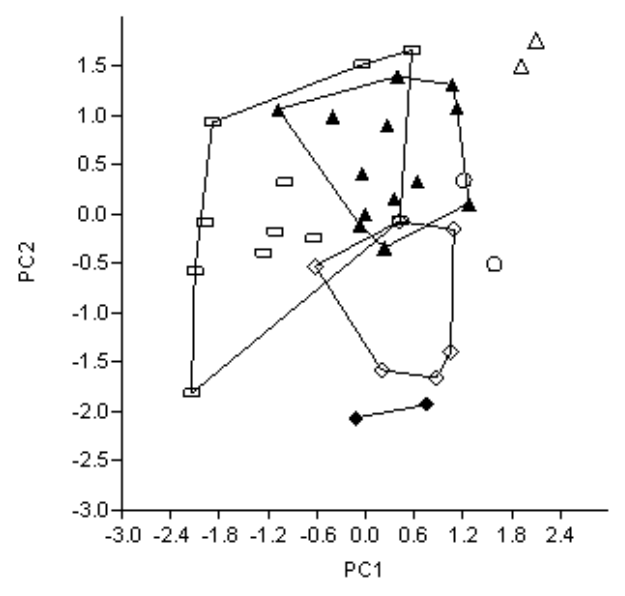

Fig. 8. Scatterplot of PC2 against PC1 for a PCA on 10 meristics $(\mathrm{n}=42)$ of $E$. cf. atromaculatus (Nichols \& Griscom, 1917): Ituri $5(\diamond)$, Ituri $6(\diamond)$, Ituri/‘Kisangani region’ $(\Delta)$, Epulu $2(\boldsymbol{\Delta})$, and Ituri 8 $(\square)$. Also shown are the type specimens of E. atromaculatus (Nichols \& Griscom, 1917) (०). 
variation among different populations, the detected morphological and genetic differences among the examined specimens of Enteromius, suggests that these populations probably represent separate, undescribed species. Although DNA barcodes allowed for the clustering of putative conspecifics, the obtained tree does not necessarily reflect the phylogenetic relationships within the genus Enteromius. A review of the phylogeny would not only require a comprehensive sampling of all species of Enteromius (some 200 species), but also the inclusion of outgroups. Nevertheless, some scenarios can be proposed concerning their evolutionary history. As in each of the geographically isolated river stretches studied distinct putative species appear to occur, allopatric speciation may well have been the main mode of speciation in this genus. However, the phylogenetic relationships among the species remain largely unresolved, as there is a lack of resolution in several parts of the ML tree. While it is possible that the lack of resolution is due to incomplete taxon sampling and/or to the small number of characters, we suggest a plausible cause to be rapid radiation, which often results in difficulties in resolving phylogenetic patterns (Fernández \& Vrba 2005; Koblmüller et al. 2010). The unresolved phylogenies would in that case be the result of an almost concurrent differentiation between populations from different river stretches on a short evolutionary timescale. The fact that in this scenario adaptation to different niches has not been necessary, could thus be the cause that only minor morphological differences exist, which were only detected after multivariate exploratory techniques.

For E. cf. atromaculatus and E. cf. pellegrini, the populations from the Ituri River and its most important right-bank affluent, the Epulu River, have a slightly different colour pattern, which seems to support the scenario of allopatric speciation. However, for E. cf. atromaculatus, there was only a genetic divergence of $1.75 \%$ between these populations (Epulu 2 and Ituri 8 on Fig. 2A), and even no divergence for E. cf. pellegrini (Ituri/Epulu on Fig. 2A). Also based on counts and measurements, both populations of E. cf. atromaculatus (e.g., Figs 8-9) and E. cf. pellegrini (not illustrated) overlap. These two instances could be examples of intraspecific geographical colour variation rather than of two separate species in each of the two groups. This conclusion is unexpected, since even morphologically very similar populations were found to represent separate putative species in almost every individual river stretch. The observation that the populations from the Ituri and the Epulu cannot be distinguished based on the

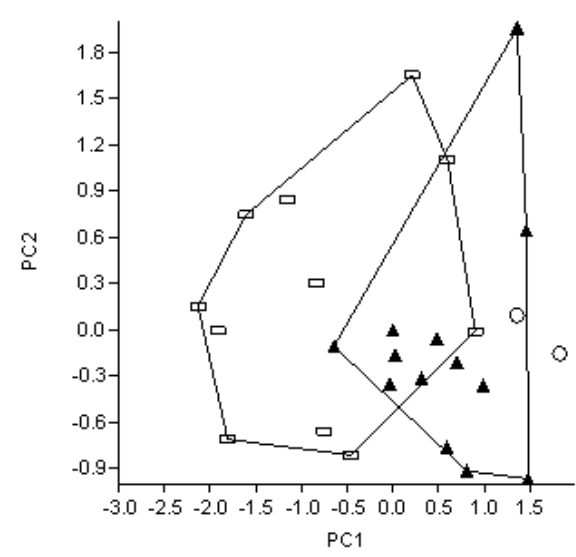

Fig. 9. Scatterplot of PC2 against PC1 for a PCA on 10 meristics $(\mathrm{n}=36)$ of $E$. cf. atromaculatus (Nichols \& Griscom, 1917): Epulu $2(\boldsymbol{\Delta})$, and Ituri $8(\boldsymbol{\square})$. Also shown are the type specimens of E. atromaculatus (Nichols \& Griscom, 1917) (०). 
multivariate analyses and do not appear to be genetically distinct, is even more surprising since these two river stretches are isolated. Indeed, the discussed populations are separated from each other by the presence of two waterfalls, one on the Epulu, just upstream of its confluence with the Ituri, and one on the Ituri itself (Vreven, RMCA, pers. comm.). These falls could form important barriers for fish species and populations, at least for upstream dispersal. However, this hypothesis does not appear to be supported by our results.

Interestingly, in some rivers multiple lineages of the same 'a priori' species appear to co-exist. This implies that in some instances morphologically similar putative (a posteriori) species may occur in sympatry; this is, e.g., the case for three lineages of E. cf. miolepis in the Luapula and two in the Luki River. Why morphologically very similar but separate species have evolved in the same rivers cannot be inferred from the present data set, and would require a phylogenetic analysis on multiple genetic markers and, e.g., additional information on ecology.

The distribution patterns, in combination with morphological (dis)similarities and the unresolved phylogenetic relationships, indicate that multiple allopatric speciation events on a short evolutionary timescale is a plausible mode of speciation for the examined species of Enteromius. Such allopatric divergences can occur in river systems when hydrological changes cause (simultaneous) disconnections of river stretches. Remarkably, some morphologically similar putative species occur however in sympatry.

\section{Impact on documented species richness}

By applying DNA barcoding in combination with multivariate analyses of morphometric data to several Enteromius populations from the Congo basin and the relevant type specimens, the number of species identified has increased from four based on literature to putatively 23. Considering the fact that only a part of the Congo basin and only some species have been studied, our results could imply a considerable increase of the number of species within this genus when extrapolated to the entire Congo basin or even Africa as a whole. A similar approach applied to other tropical vertebrates has yielded similar results. For instance, in a study on African giant pouched rats (Cricetomys, Nesomyidae), the combined use of DNA barcoding and cranial measurements lead to the discovery of at least three new species (Olayemi et al. 2012). Also for the fish genus Pseudobarbus (Cyprinidae) occurring in southern Africa, 15 separate lineages were identified, using cytb and $16 \mathrm{~S}$ data, within the (at that time) seven valid species within the genus, most of which were confirmed by morphological results (Swartz et al. 2009). Also in Neotropical frogs, a study based on 16S rDNA indicated a huge underestimation of the current species richness, as up to $115 \%$ additional species were discovered (Fouquet et al. 2007). In the latter study however, no morphological analyses were performed to support the validity of the putative new species. These different studies indicate that not only for African fishes, but for several other vertebrate taxa in different regions on Earth, the current species richness could be severely underestimated. However, every case has its specific patterns, which indicates that a taxon-specific approach is needed for species detection and delineation. Systematically using a multidisciplinary approach could therefore result in an enormous increase of the overall documented species richness.

Correct insight in the number of species within a certain taxon is urgently needed to address conservation issues. When the number of species is highly underestimated, the decline of species may also be far worse than initially detected (Fouquet et al. 2007). Therefore, using molecular techniques can be of key importance for traditional taxonomy in accelerating the pace of species detection and description.

\section{Acknowledgements}

We would like to thank Koen De Gelas for his help in the lab as well as James Maclaine (NHM), Patrice Pruvost (MNHN) and Barbara Brown (AMNH) for the loan of type specimens under their care. We 
are grateful to Emmanuel Vreven (RMCA) for providing literature-based compilations of the species of Enteromius, and for sampling the "Réserve de Faunes à Okapi", Epulu region and in the Ituri River; these expeditions were funded by the 'Leopold III-Fonds voor Natuuronderzoek en Natuurbehoud', 'Directorate-General for Development Cooperation and Humanitarian Aid' and the 'Stichting tot Bevordering van het Wetenschappelijk Onderzoek in Afrika'. The expedition to the Kisangani area in 2013 was funded by the BELSPO Science for a Sustainable Development (SSD) project entitled 'Congo basin: from carbon to fishes' (COBAFISH). This study is part of the $\mathrm{PhD}$ research of E.D., funded by a BELSPO action 2 programme.

\section{References}

Agnèse J.F., Berrebi P., Lévêque C. \& Guégan J.F. 1990. Two lineages, diploid and tetraploid, demonstrated in African species Barbus (Osteichthyes, Cyprinidae). Aquatic Living Resources 3: 305311. https://doi.org/10.1051/alr:1990031

Bamba M. 2012. The 'Barbus' species (Cypriniformes, Cyprinidae) from Côte d'Ivoire: A Systematic Revision of Some West African Species Complexes. PhD thesis, KU Leuven, Belgium.

Bamba M., Vreven E.J. \& Snoeks J. 2011. Description of Barbus teugelsi sp. nov. (Cypriniformes: Cyprinidae) from the Little Scarcies basin in Guinea, Africa. Zootaxa 2988: 48-65.

Banyankimbona G., Vreven E. \& Snoeks J. 2012. 'Barbus'devosi, new species from the Malagarazi River basin in Burundi and Tanzania, East Africa (Cypriniformes: Cyprinidae). Ichthyological Exploration of Freshwaters 23: 181-192.

Becker S., Hanner R.H. \& Steinke D. 2011. Five years of FISH-BOL: Brief status report. Mitochondrial DNA 22: 3-9. https://doi.org/10.3109/19401736.2010.535528

Berrebi P. \& Tsigenopoulos C.S. 2003. Phylogenetic organization of the genus Barbus sensu stricto: A review based on data obtained using molecular markers. In: Bãnãrescu P.M. \& Bogutskaya N.G. (eds) The Freshwater Fishes of Europe Volume 5/II Cyprinidae 2, Part II: Barbus: 11-22. Aula-Verlag, Wiesbaden.

Berrebi P. \& Valiushok D. 1998. Genetic divergence among morphotypes of Lake Tana (Ethiopia) barbs. Biological Journal of the Linnean Society 64: 369-384. https://doi.org/10.1111/j.1095-8312.1998. tb00338.x

Berrebi P., Kottelat M., Skelton P. \& Rab P. 1996. Systematics of Barbus: State of the art and heuristic comments. Folia Zoologica 45: 5-12.

Berrebi P., Chenuil A., Kotlik P., Machordom A. \& Tsigenopoulos C.S. 2014. Disentangling the evolutionary history of the genus Barbus sensu latu, a twenty years adventure. In: Alves M.J., Cartaxana A., Correia A.M. \& Lopes L.F. (eds) Professor Carlos Almaça (1934-2010) - Estado da arte em áreas cientificas do seu interesse: 29-55. Museu Nacional de História Natural e da Ciência, Lisboa.

Bookstein F.L., Chernoff B., Elder R.L., Humphries J.M., Smith G.R. \& Strauss R.E. 1985. Morphometrics in Evolutionary Biology: the Geometry of Size and Shape Change, with Examples from Fishes. Academy of Natural Sciences of Philadelphia, Philadelphia.

Collins R.A. \& Cruickshank R.H. 2012. The seven deadly sins of DNA barcoding. Molecular Ecology Resources 13: 969-975. https://doi.org/10.1111/1755-0998.12046

Decru E., Vreven E. \& Snoeks J. 2012. A revision of the West African Hepsetus (Characiformes; Hepsetidae) with a description of $H$. akawo sp. nov. and a redescription of $H$. odoe (Bloch, 1794). Journal of Natural History 46: 1-23. https://doi.org/10.1080/00222933.2011.622055

Decru E., Moelants T., De Gelas K., Vreven E., Verheyen E. \& Snoeks J. 2016. Taxonomic challenges in freshwater fishes: a mismatch between morphology and DNA barcoding in fish of the north-eastern 
part of the Congo basin. Molecular Ecology Resources 16: 342-352. https://doi.org/10.1111/1755$\underline{0998.12445}$

DeSalle R., Egan M.G. \& Siddall M. 2011. The unholy trinity, taxonomy, species delimitation and DNA barcoding. Philosophical Transactions of the Royal Society B 360: 1905-1916. https://doi.org/10.1098/ $\underline{\text { rstb.2005.1722 }}$

Edgar R.C. 2004. MUSCLE: multiple sequence alignment with high accuracy and high throughput. Nucleic Acids Research 32: 1792-1797. https://doi.org/10.1093/nar/gkh340

Fernández M.H. \& Vrba E.S. 2005. A complete estimate of the phylogenetic relationships in Ruminantia: a dated species-level supertree of the extant ruminants. Biological Reviews 80: 269-302. https://doi. org/10.1017/s1464793104006670

Fouquet A., Gilles A., Vences M., Marty C., Blanc M. \& Gemmell N.J. 2007. Underestimation of species richness in Neotropical frogs revealed by mtDNA analyses. PLoS ONE 2: e1109. https://doi. org/10.1371/journal.pone.0001109

Froese R. \& Pauly D. 2017. FishBase. Available from www.fishbase.org [accessed 30 Mar. 2017].

Golubtsov A.S. \& Krysanov E.Y. 1993. Karyological study of some cyprinid species from Ethiopia. The ploidy differences between large and small Barbus of Africa. Journal of Fish Biology 42: 445-455. https://doi.org/10.1111/j.1095-8649.1993.tb00347.x

Goodier S.A.M., Cotterill F.P.D., O’Ryan C., Skelton P.H. \& de Wit M.J. 2011. Cryptic diversity of African Tigerfish (Genus Hydrocynus) reveals palaeogeographic signatures of linked Neogene geotectonic events. PLoS ONE 6: e28875. https://doi.org/10.1371/journal.pone.0028775

Hammer Ø., Harper D.A.T. \& Ryan P.D. 2001. PAST: Paleontological statistics software package for education and data analysis. Palaeontologia Electronica 4: 1-9.

Hebert P.D.N., Cywinska A., Ball S.L. \& de Waard J.R. 2003. Biological identifications through DNA barcodes. Proceedings of the Royal Society B 270: 313-321. https://doi.org/10.1098/rspb.2002.2218

Ivanova N.V., Zemlak T.S., Hanner R.H. \& Hebert P.D. 2007. Universal primer cocktails for fish DNA barcoding. Molecular Ecology Notes 7: 544-548. https://doi.org/10.1111/j.1471-8286.2007.01748.x

Koblmüller S., Egger B., Sturmbauer C. \& Sefc K.M. 2010. Rapid radiation, ancient incomplete lineage sorting and ancient hybridization in the endemic Lake Tanganyika cichlid tribe Tropheini. Molecular Phylogenetics and Evolution 55: 318-334. https://doi.org/10.1016/j.ympev.2009.09.032

Lavoué S. \& Sullivan J.P. 2014. Petrocephalus boboto and Petrocephalus arnegardi, two new species of African electric fish (Osteoglossomorpha, Mormyridae) from the Congo River basin. ZooKeys 400: 43-65. https://doi.org/10.3897/zookeys.400.6743

Lévêque C. \& Daget J. 1984. Cyprinidae. In: Daget J., Gosse J.P. \& Van den Audenaerde T.D. (eds) Check-list of the Freshwater Fishes of Africa (CLOFFA1): 217-342. ORSTOM \& MRAC, Paris \& Tervuren.

Lowenstein J.H., Osmundson T.Z., Becker S., Hanner R. \& Stiassny M.L.J. 2011. Incorporating DNA barcodes into a multi-year inventory of the fishes of the hyperdiverse Lower Congo River, with a multigene performance assessment of the genus Labeo as a case study. Mitochondrial DNA 21: 1-19. https:// doi.org/10.3109/19401736.2010.537748

Messing J. 1983. New M13 vectors for cloning. Methods in Enzymology 101: 20-78. https://doi. org/10.1016/0076-6879(83)01005-8

Oellermann L.K. \& Skelton P.H. 1990. Hexaploidy in yellowfish species (Barbus, Pisces, Cyprinidae) from southern Africa. Journal of Fish Biology 37: 105-115. https://doi.org/10.1111/j.1095-8649.1990. $\underline{\mathrm{tb} 05932 . \mathrm{x}}$ 
Olayemi A., Nicolas V., Hulselmans J.A.N., Missoup A.D., Fichet-Calvet E., Amundala D., Dudu A., Dierckx T., Wendelen W., Leirs H. \& Verheyen E. 2012. Taxonomy of the African giant pouched rats (Nesomyidae: Cricetomys): molecular and craniometric evidence support an unexpected high species diversity. Zoological Journal of the Linnean Society 165: 700-719. https://doi.org/10.1111/j.1096$\underline{3642.2012 .00823 . x}$

Pereira L.H.G., Hanner R., Foresti F. \& Oliveira C. 2013. Can DNA barcoding accurately discriminate megadiverse Neotropical freshwater fish fauna? BMC Genetics 14: 20. https://doi.org/10.1186/14712156-14-20

Pethiyagoda R., Meegaskumbura M. \& Maduwage K. 2012. A synopsis of the South Asian fishes referred to Puntius (Pisces: Cyprinidae). Ichthyological Exploration of Freshwaters 23: 69-95.

Poll M. 1976. Exploration du Parc National de l'Upemba Mission G.F. de Witte, 73: Poissons. Fondation pour favoriser les recherches scientifiques en Afrique, Bruxelles.

Rab P., Machordom A., Perdices A. \& Guegan J.F. 1995. Karyotypes of three «small» Barbus species (Cyprinidae) from Republic of Guinea (Western Africa) with a review on karyology of African small Barbus. Caryologia 48: 299-307. https://doi.org/10.1080/00087114.1995.10797339

Ren Q. \& Mayden R.L. 2016. Molecular phylogeny and biogeography of African diploid barbs, 'Barbus', and allies in Africa and Asia (Teleostei: Cypriniformes). Zoologica Scripta 45 (6): 642-649. https://doi. org $/ 10.1111 /$ zsc. 12177

Runge J. 2007. The Congo River, Central Africa. In: Gupta A. (ed.) Large Rivers: Geomorphology and Management: 293-309. John Wiley \& Sons Ltd, West Sussex.

Schmidt R.C. \& Bart Jr. H.L. 2015. Nomenclatural changes should not be based on equivocally supported phylogenies: Reply to Yang et al. 2015. Molecular Phylogenetics and Evolution 90: 193-194. https:// doi.org/10.1016/j.ympev.2015.05.025

Snoeks J. 2004. The Cichlid Diversity of Lake Malawi/Nyassa/Niassa: Identification, Distribution and Taxonomy. Cichlid Press, Texas.

Snoeks J., Harrison I.J. \& Stiassny M.L.J. 2011. The status and distribution of freshwater fishes. In: Darwall W., Smith K., Allen D., Holland R., Harrison I. \& Brooks E. (eds) The Diversity of Life in African Freshwaters: Underwater, under Threat. An Analysis of the Status and Distribution of Freshwater Species throughout Mainland Africa: 42-91. IUCN, Gland \& Cambridge.

Steinke D. \& Hanner R. 2011. The FISH-BOL collaborators' protocol. Mitochondrial DNA 22: 10-14. https://doi.org/10.3109/19401736.2010.536538

Stiassny M.L., Denton J.S. \& Monsebula Iyaba R.J.C. 2013. A new ectoparasitic distichodontid of the genus Eugnathichthys (Characiformes: Citharinoidei) from the Congo basin of central Africa, with a molecular phylogeny for the genus. Zootaxa 3693: 479-490. https://doi.org/10.11646/zootaxa.3693.4.4

Swartz E.R., Skelton P.H. \& Bloomer P. 2009. Phylogeny and biogeography of the genus Pseudobarbus (Cyprinidae): shedding light on the drainage history of rivers associated with the Cape Floristic Region. Molecular Phylogenetics and Evolution 51: 75-84. https://doi.org/10.1016/j.ympev.2008.10.017

Tamura K., Peterson D., Peterson N., Stecher G., Nei M. \& Kumar S. 2011. MEGA5: molecular evolutionary genetics analysis using maximum likelihood, evolutionary distance, and maximum parsimony methods. Molecular Biology and Evolution 28: 2731-2739. https://doi.org/10.1093/molbev/ $\underline{\operatorname{msr} 121}$

Tsigenopoulos C.S., Kasapidis P. \& Berrebi P. 2010. Phylogenetic relationships of hexaploid large-sized barbs (genus Labeobarbus, Cyprinidae) based on mtDNA data. Molecular Phylogenetics and Evolution 56: 851-856. https://doi.org/10.1016/j.ympev.2010.02.006 
Tweddle D. \& Skelton P.H. 2008. New species of 'Barbus' and Labeobarbus (Teleostei: Cyprinidae) from the South Rukuru River, Malawi, Africa. Smithiana Publications in Aquatic Biodiversity, Bulletin 8: 25-39.

Yang L., Sado T., Hirt M.V., Pasco-Viel E., Arunachalam M., Li J., Wang X., Freyhof J., Saitoh K., Simons A.M., Miya M., He S. \& Mayden R.L. 2015. Phylogeny and polyploidy: Resolving the classification of cyprinine fishes (Teleostei: Cypriniformes). Molecular Phylogenetics and Evolution 85: 97-116. https:// doi.org/10.1016/j.ympev.2015.01.014

Manuscript received: 3 June 2016

Manuscript accepted: 24 August 2016

Published on: 12 April 2017

Topic editor: Rudy Jocqué

Desk editor: Kristiaan Hoedemakers

Printed versions of all papers are also deposited in the libraries of the institutes that are members of the EJT consortium: Muséum national d'Histoire naturelle, Paris, France; Botanic Garden Meise, Belgium; Royal Museum for Central Africa, Tervuren, Belgium; Natural History Museum, London, United Kingdom; Royal Belgian Institute of Natural Sciences, Brussels, Belgium; Natural History Museum of Denmark, Copenhagen, Denmark; Naturalis Biodiversity Center, Leiden, the Netherlands. 


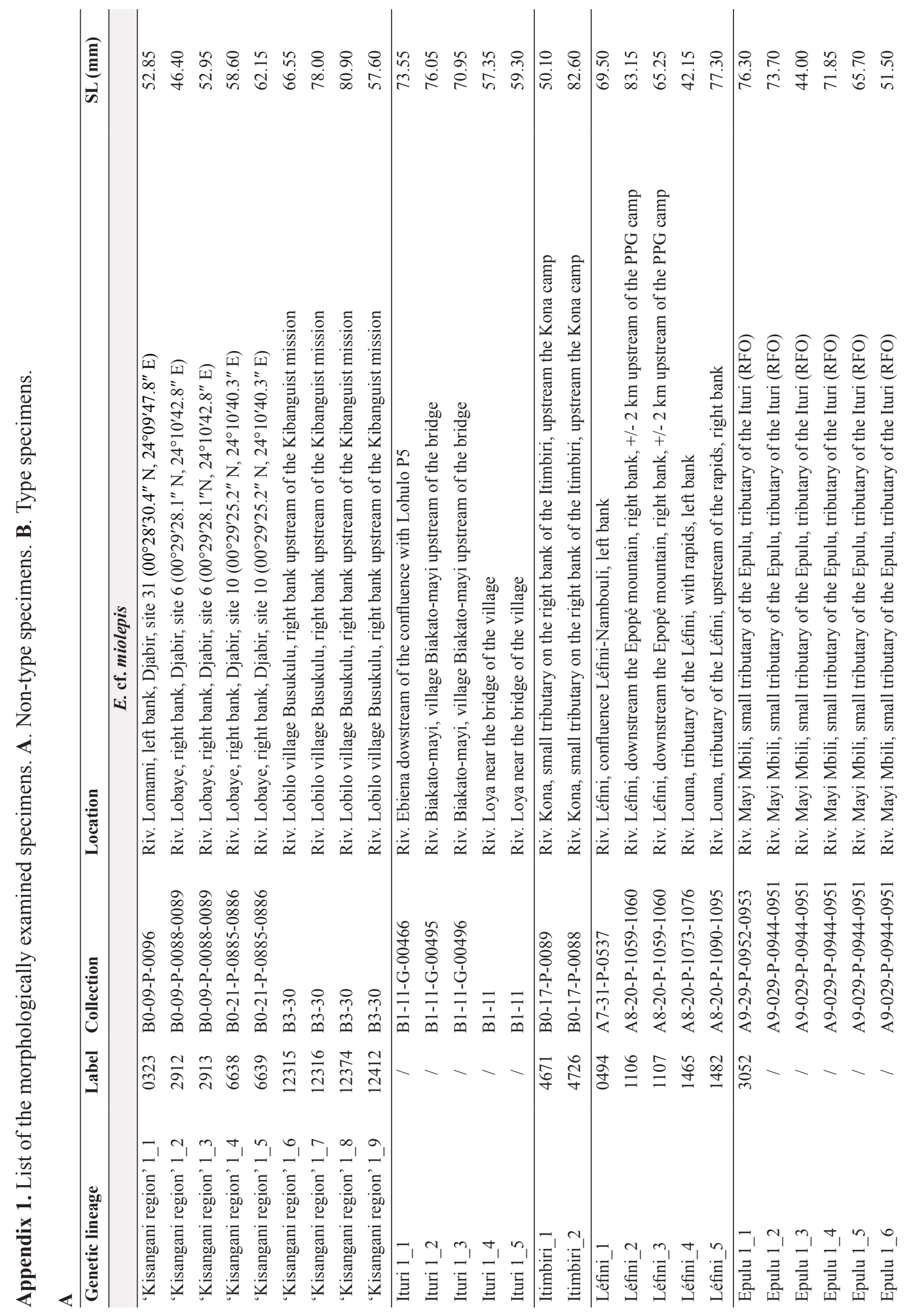


ำค๙

$\cong \& 尺 \approx n$ in

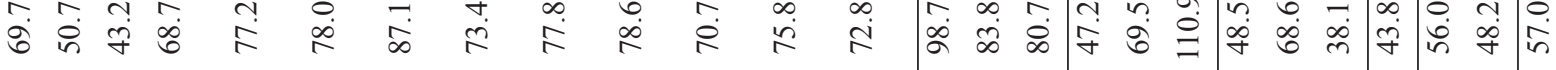

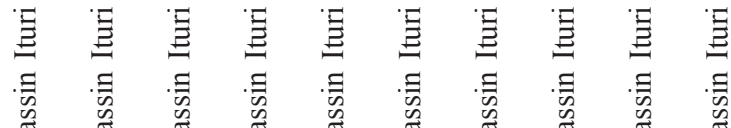

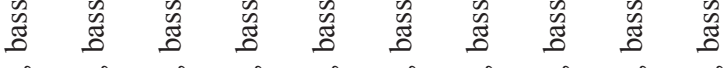

言言言言言言言言言言言

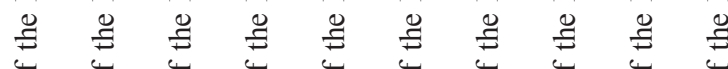

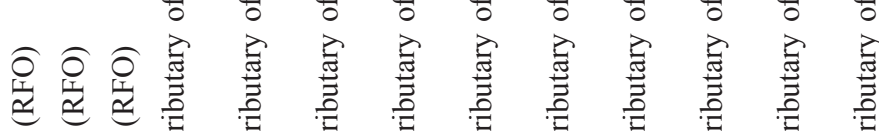

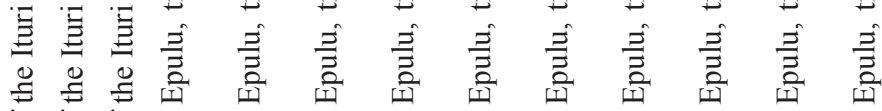

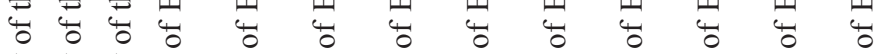

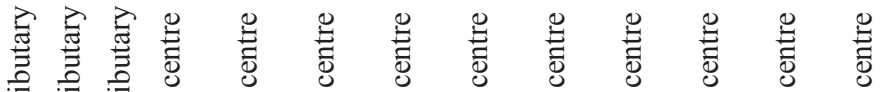

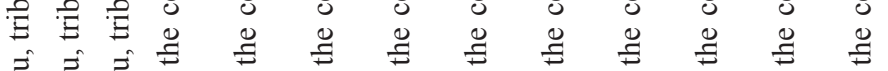

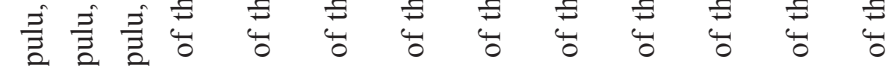

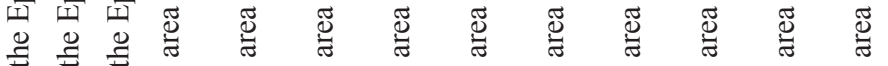

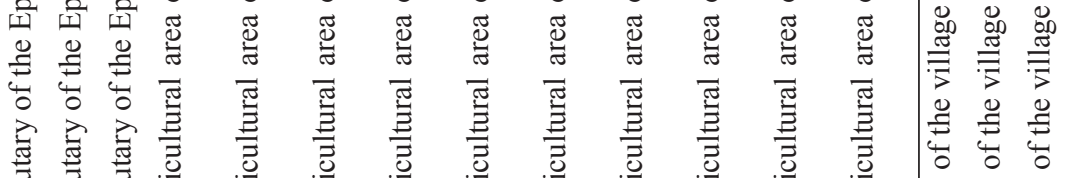

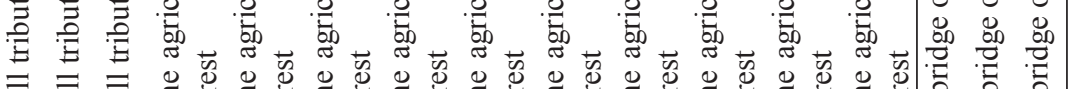

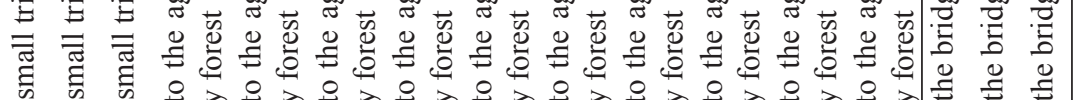

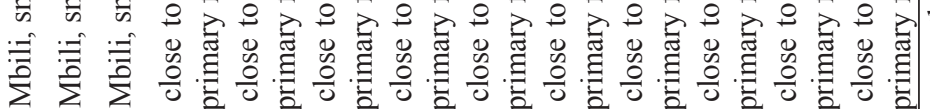

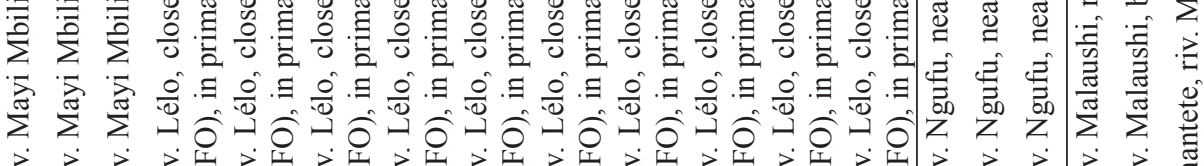

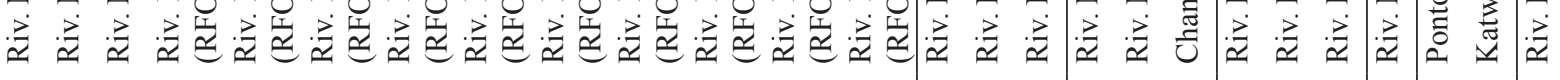

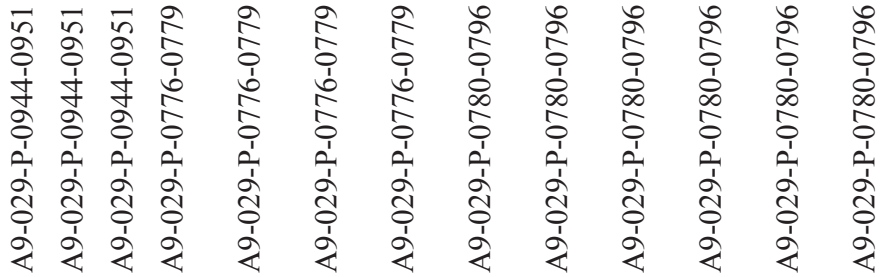

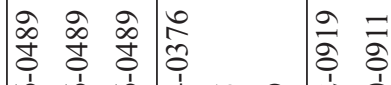

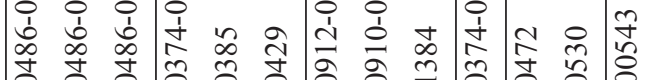

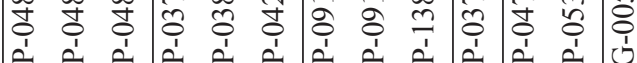

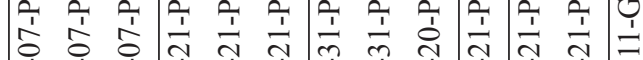

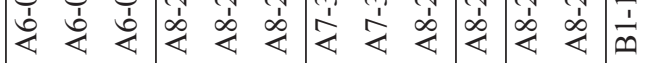

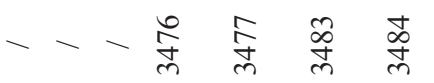

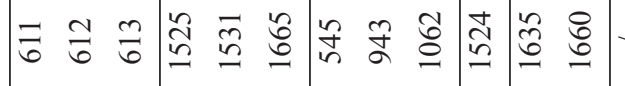

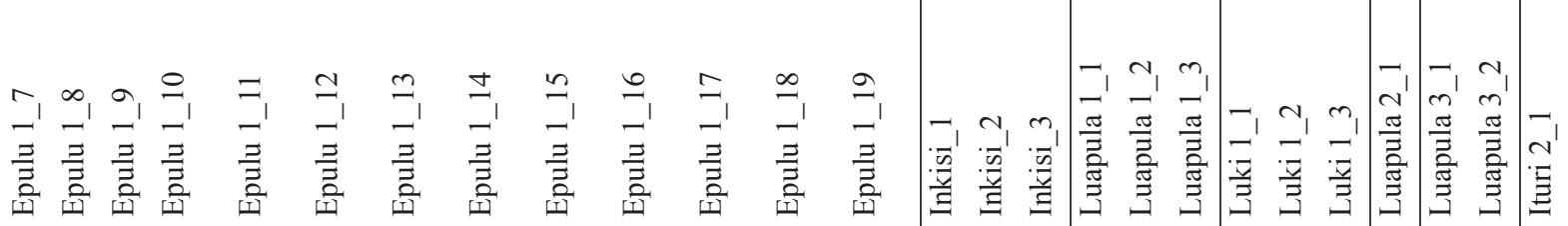









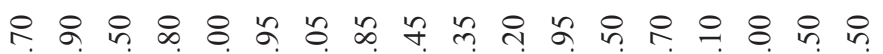

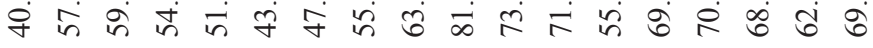

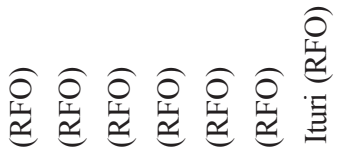

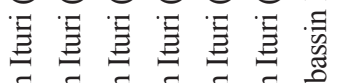

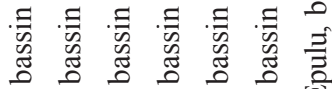

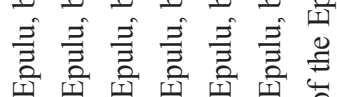

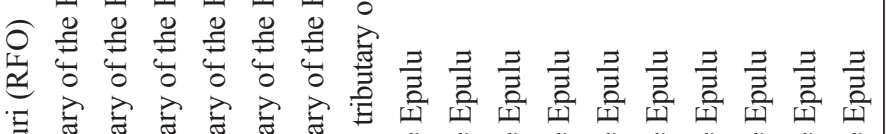

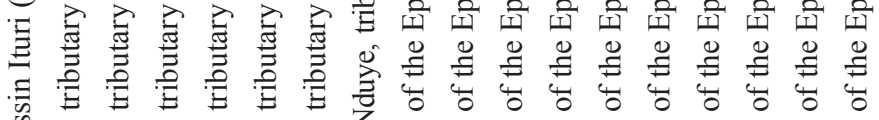

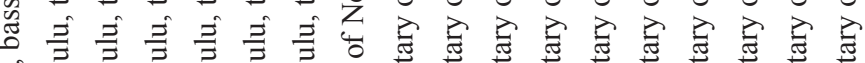

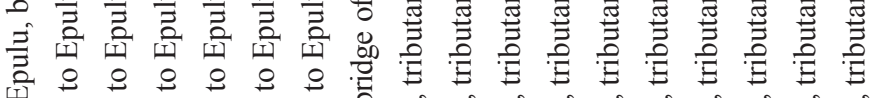

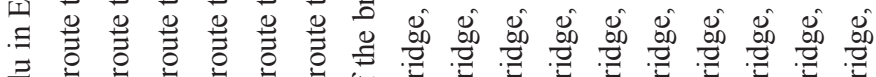

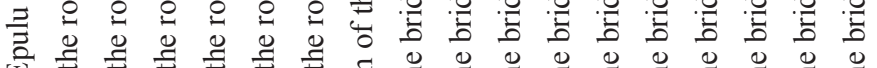

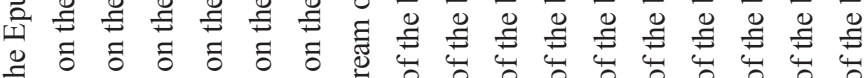

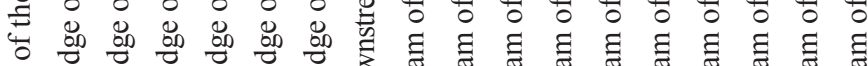

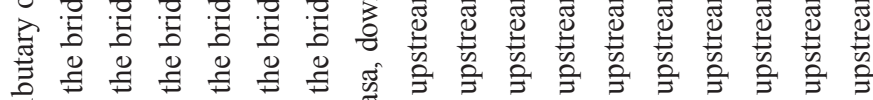

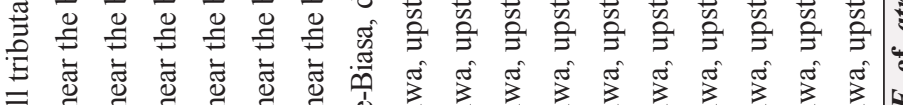
击

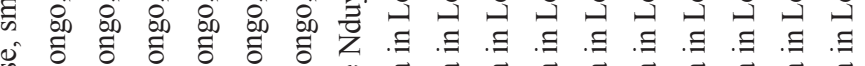

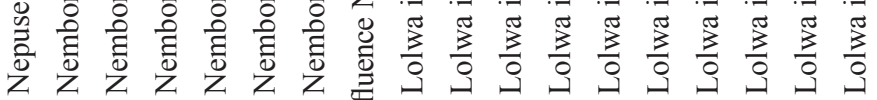

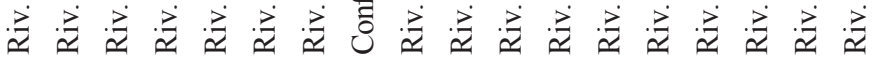

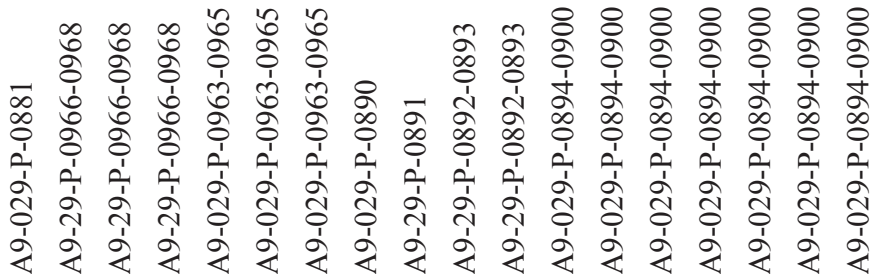

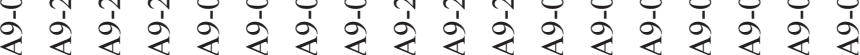

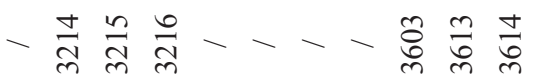

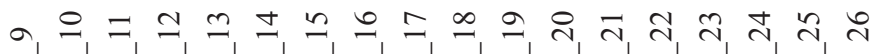

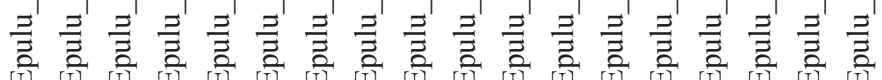

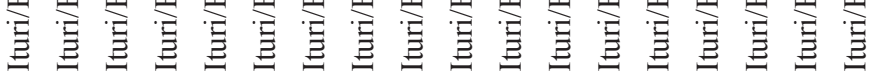

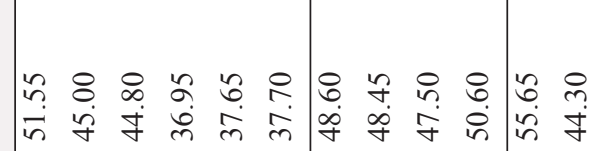

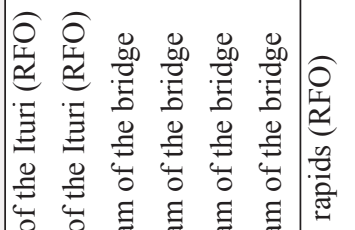

फ

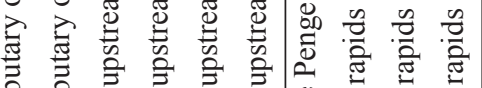

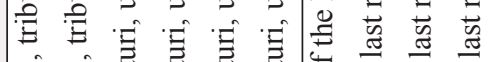

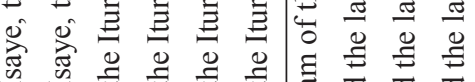

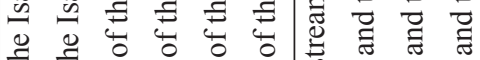

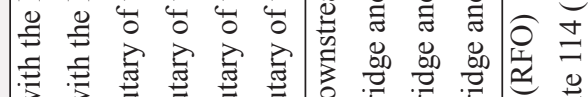

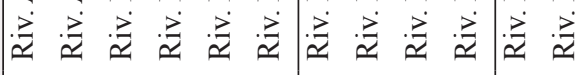

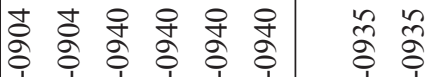

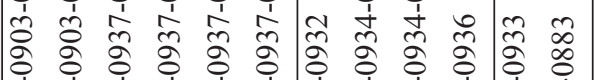

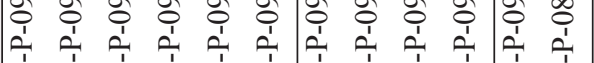

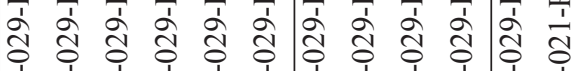

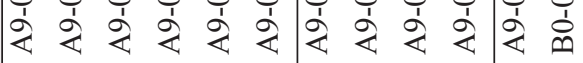

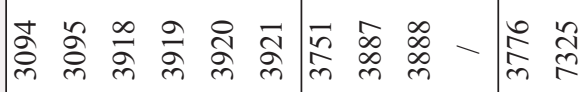

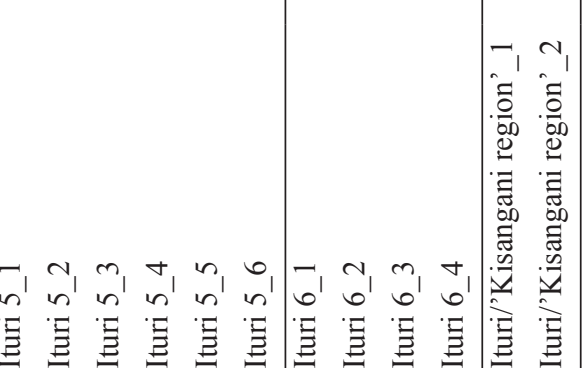




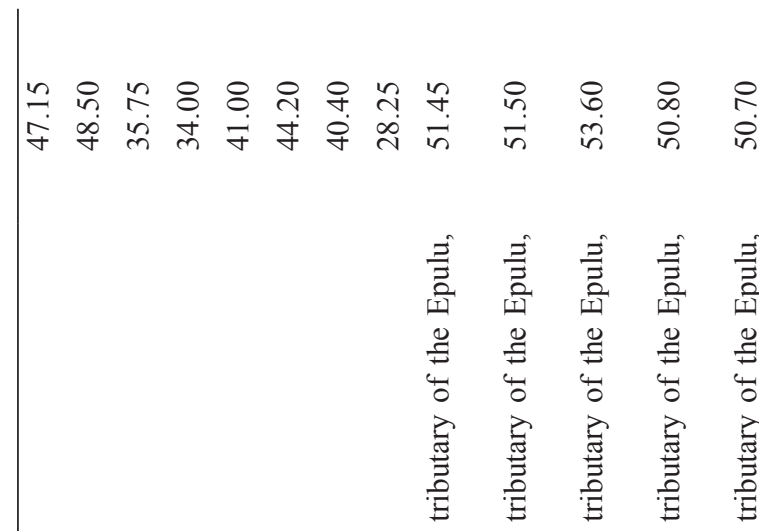

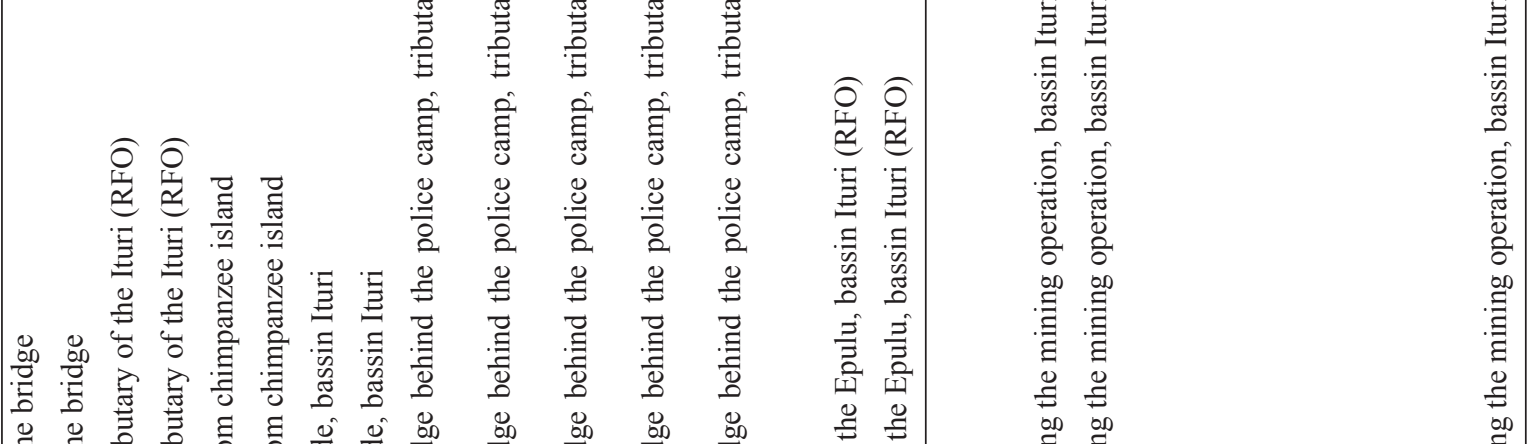

焉

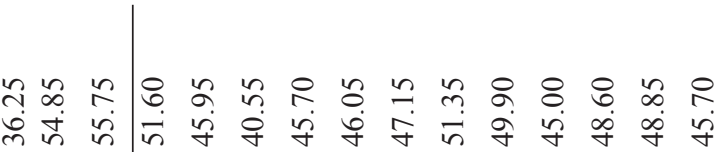

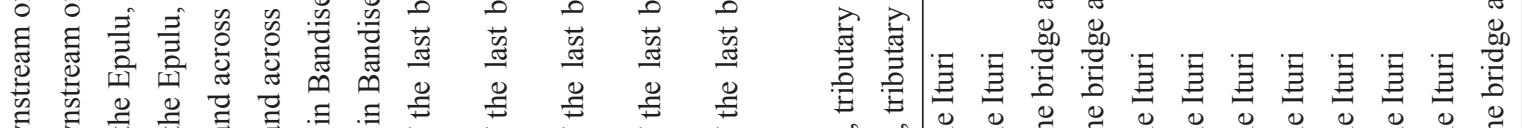

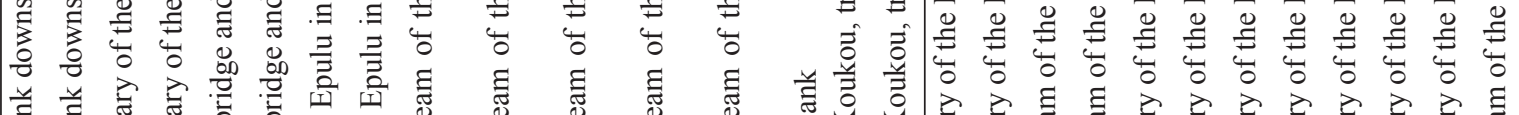

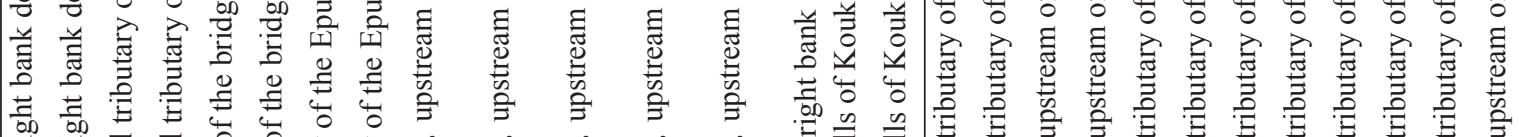

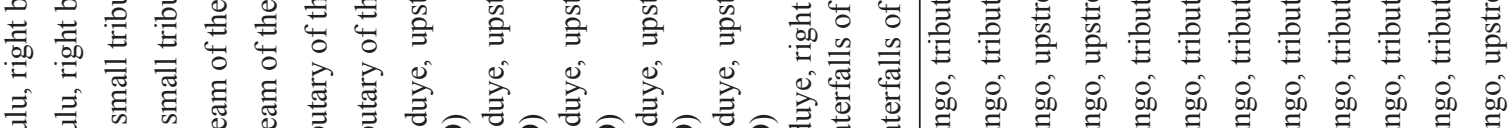

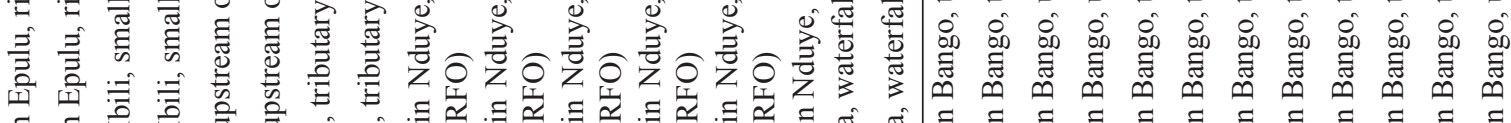

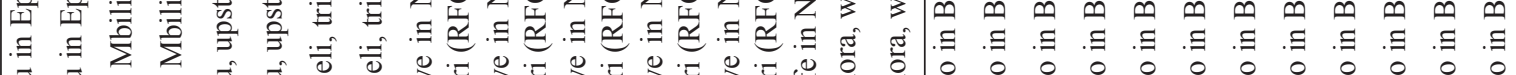

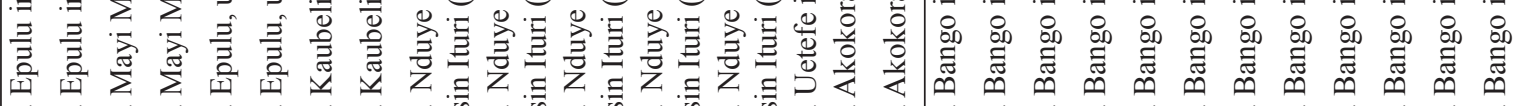

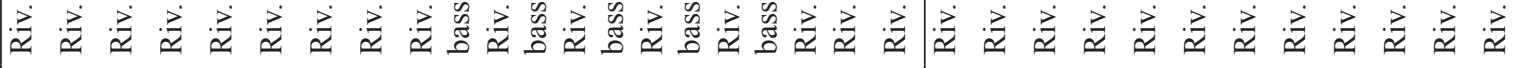

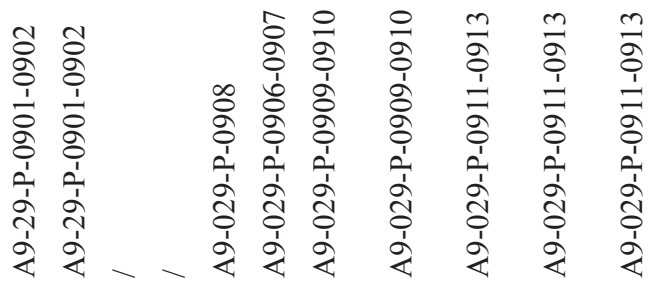

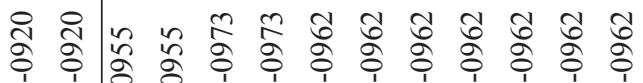

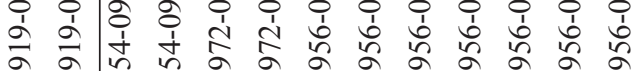

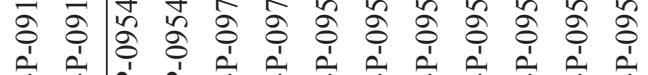

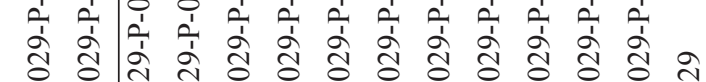

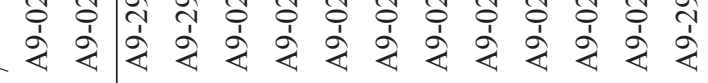

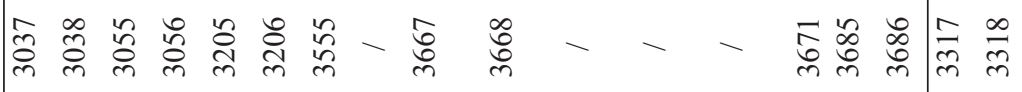

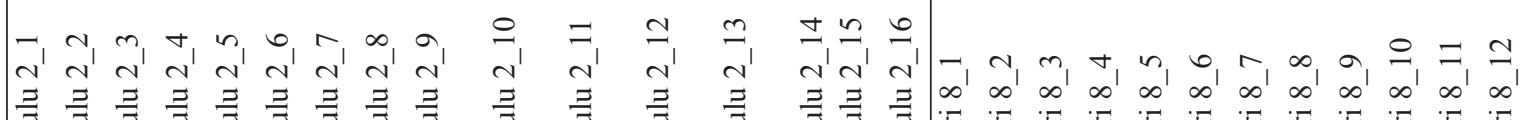

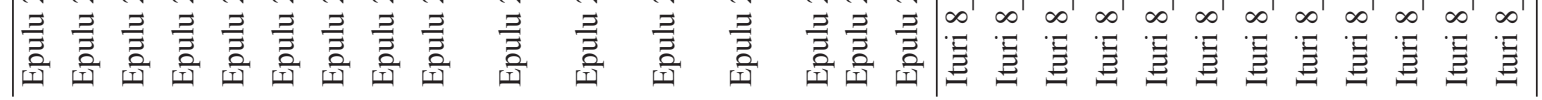




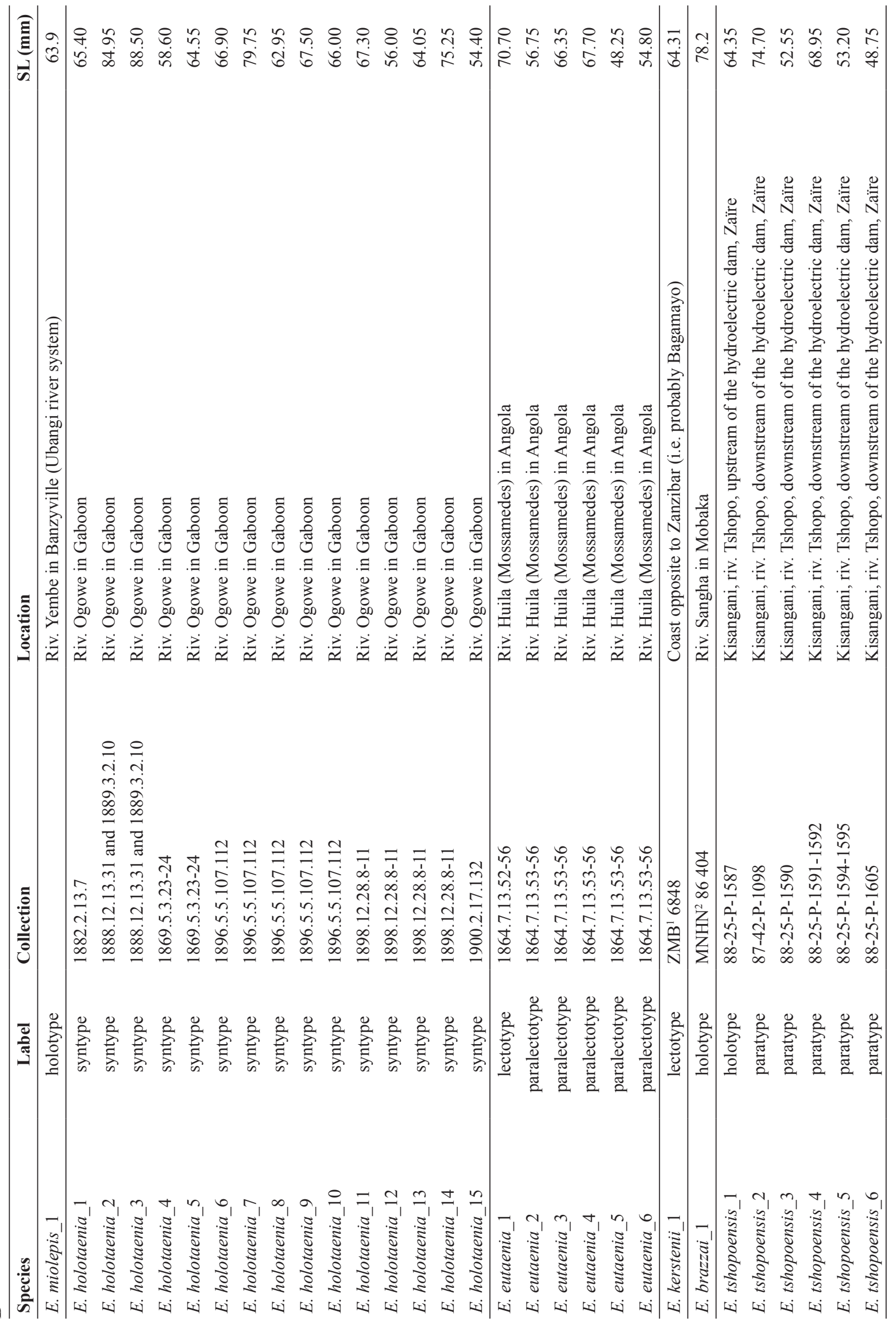




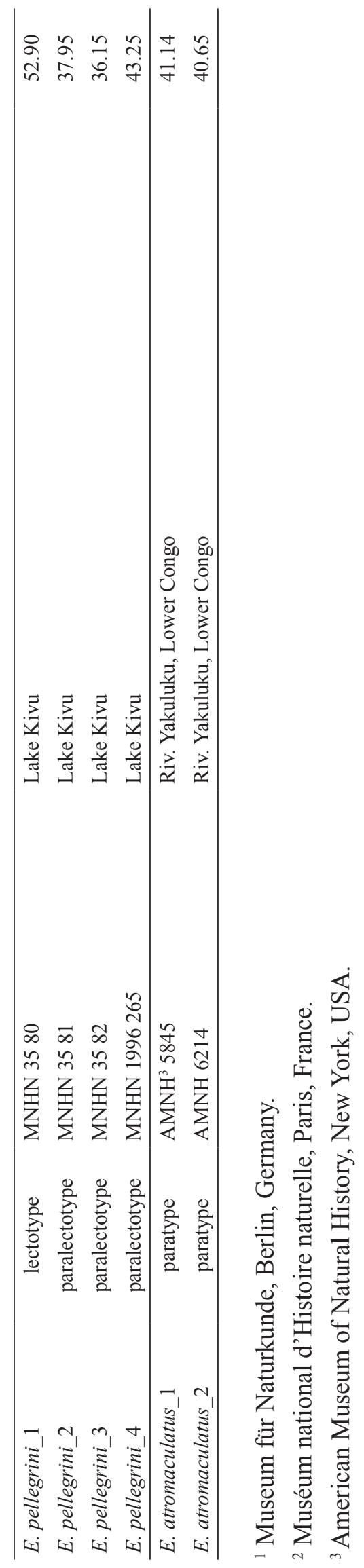


Appendix 2. PC loadings of the PCA in Fig. 3. Most important loadings indicated in bold.

\begin{tabular}{lccc}
\hline & PC1 & PC2 & PC3 \\
\hline LogSL & 0.229 & 0.158 & -0.033 \\
LogHL & 0.236 & 0.018 & -0.037 \\
LogED & $\mathbf{0 . 2 7 1}$ & $\mathbf{- 0 . 6 2 6}$ & $-\mathbf{0 . 6 6 1}$ \\
LogSnL & $\mathbf{0 . 2 7 9}$ & -0.060 & 0.230 \\
LogPrOpD & 0.244 & -0.062 & -0.003 \\
LogIOW & 0.232 & 0.163 & -0.091 \\
LogPrDD & 0.229 & 0.210 & -0.148 \\
LogPoDD & 0.238 & 0.289 & 0.068 \\
LogDoFBL & 0.242 & -0.310 & $\mathbf{0 . 3 9 5}$ \\
LogDoFL & 0.216 & $\mathbf{- 0 . 3 1 0}$ & $\mathbf{0 . 5 2 8}$ \\
LogPrPecD & 0.224 & 0.030 & -0.005 \\
LogPrPelD & 0.233 & 0.074 & -0.011 \\
LogPrAD & 0.236 & 0.061 & -0.096 \\
LogPoAD & 0.223 & $\mathbf{0 . 4 6 0}$ & -0.160 \\
LogBD & $\mathbf{0 . 2 7 5}$ & 0.060 & 0.005 \\
LogMxCPD & 0.260 & -0.057 & 0.045 \\
LogMnCPD & 0.247 & 0.024 & 0.043 \\
\hline
\end{tabular}

Appendix 3. PC loadings of the PCA in Fig. 4. Most important loadings indicated in bold.

\begin{tabular}{lccc}
\hline & PC1 & PC2 & PC3 \\
\hline LL Sc & 0.242 & $\mathbf{0 . 5 3 8}$ & 0.195 \\
D-L Sc & $\mathbf{0 . 4 4 0}$ & -0.005 & -0.196 \\
PD Sc & 0.311 & $\mathbf{0 . 3 7 6}$ & -0.047 \\
CP Sc & 0.288 & 0.327 & -0.043 \\
LP Sc & $\mathbf{0 . 3 7 1}$ & -0.339 & 0.376 \\
L-B Sc & $\mathbf{0 . 4 4 1}$ & -0.213 & $\mathbf{0 . 3 9 7}$ \\
DFR & -0.258 & -0.285 & 0.213 \\
AFR & -0.056 & 0.090 & $\mathbf{- 0 . 5 1 3}$ \\
PecFR & -0.248 & 0.312 & 0.224 \\
PelFR & -0.325 & $\mathbf{0 . 3 4 1}$ & $\mathbf{0 . 5 1 3}$ \\
\hline
\end{tabular}


Appendix 4. PC loadings of the PCA in Fig. 5. Most important loadings indicated in bold.

\begin{tabular}{lccc}
\hline & PC1 & PC2 & PC3 \\
\hline LL Sc & $\mathbf{0 . 9 4 0}$ & -0.040 & -0.023 \\
D-L Sc & 0.139 & -0.097 & -0.084 \\
PD Sc & 0.136 & $\mathbf{- 0 . 2 2 6}$ & $\mathbf{0 . 8 5 5}$ \\
CP Sc & $\mathbf{0 . 1 9 2}$ & -0.150 & $-\mathbf{0 . 4 1 0}$ \\
LP Sc & 0.044 & -0.033 & -0.030 \\
L-B Sc & 0.140 & -0.174 & -0.117 \\
DFR & $<0.001$ & $<0.001$ & $<-0.001$ \\
AFR & 0.029 & $\mathbf{0 . 2 3 8}$ & $\mathbf{0 . 2 7 9}$ \\
PecFR & $\mathbf{0 . 1 4 2}$ & $\mathbf{0 . 9 1 0}$ & 0.039 \\
PelFR & 0.000 & 0.000 & 0.000 \\
\hline
\end{tabular}

Appendix 5. PC loadings of the PCA in Fig. 6. Most important loadings indicated in bold.

\begin{tabular}{lccc}
\hline & PC1 & PC2 & PC3 \\
\hline LLSc & $\mathbf{0 . 4 8 0}$ & 0.251 & -0.120 \\
D-LSc & 0.395 & 0.189 & 0.404 \\
PDSc & $\mathbf{0 . 4 1 6}$ & 0.226 & $-\mathbf{0 . 5 1 9}$ \\
CPSc & $\mathbf{0 . 5 1 2}$ & 0.003 & -0.020 \\
L-BSc & 0.317 & $\mathbf{- 0 . 2 8 3}$ & $\mathbf{0 . 6 0 4}$ \\
DFR & 0.221 & $\mathbf{0 . 5 8 4}$ & 0.005 \\
AFR & 0.071 & 0.274 & -0.040 \\
PecFR & -0.154 & $\mathbf{0 . 5 9 5}$ & $\mathbf{0 . 4 3 0}$ \\
\hline
\end{tabular}


Appendix 6. PC loadings of the PCA in Fig. 7. Most important loadings indicated in bold.

\begin{tabular}{lccc}
\hline & PC1 & PC2 & PC3 \\
\hline LL Sc & $\mathbf{0 . 7 4 0}$ & -0.164 & 0.202 \\
D-L Sc & $<-0.001$ & $<-0.001$ & $<-0.001$ \\
PD Sc & -0.011 & -0.097 & $\mathbf{0 . 4 0 2}$ \\
CP Sc & -0.105 & $\mathbf{0 . 5 5 2}$ & $\mathbf{0 . 7 6 7}$ \\
LP Sc & 0.099 & -0.403 & 0.208 \\
L-B Sc & 0.132 & $\mathbf{- 0 . 5 0 1}$ & 0.284 \\
DFR & 0.031 & -0.054 & -0.034 \\
AFR & -0.071 & 0.050 & 0.007 \\
PecFR & $\mathbf{0 . 4 5 7}$ & $\mathbf{0 . 4 5 5}$ & $\mathbf{- 0 . 2 9 0}$ \\
PelFR & $\mathbf{0 . 4 4 7}$ & 0.182 & 0.026 \\
\hline
\end{tabular}

Appendix 7. PC loadings of the PCA in Fig. 8. Most important loadings indicated in bold.

\begin{tabular}{lccc}
\hline & PC1 & PC2 & PC3 \\
\hline LL Sc & $\mathbf{0 . 9 7 1}$ & -0.119 & -0.142 \\
D-L Sc & $\mathbf{0 . 1 4 4}$ & $\mathbf{0 . 2 2 3}$ & -0.096 \\
PD Sc & 0.052 & 0.219 & $-\mathbf{0 . 1 8 7}$ \\
CP Sc & 0.028 & $\mathbf{0 . 9 0 2}$ & $-\mathbf{0 . 2 2 2}$ \\
LP Sc & $<-0.001$ & $<-0.001$ & $<0.001$ \\
L-B Sc & -0.015 & 0.053 & -0.050 \\
DFR & $<-0.001$ & $<0.001$ & $<-0.001$ \\
AFR & $<-0.001$ & $<-0.001$ & $<0.001$ \\
PecFR & $\mathbf{0 . 1 7 9}$ & $\mathbf{0 . 2 6 7}$ & $\mathbf{0 . 9 2 8}$ \\
PelFR & 0.006 & 0.001 & 0.152 \\
\hline
\end{tabular}


Appendix 8. PC loadings of the PCA in Fig. 9. Most important loadings indicated in bold.

\begin{tabular}{lccc}
\hline & PC1 & PC2 & PC3 \\
\hline LL Sc & $\mathbf{0 . 9 7 1}$ & -0.073 & -0.141 \\
D-L Sc & $\mathbf{0 . 1 7 5}$ & 0.047 & $\mathbf{0 . 1 4 4}$ \\
PD Sc & 0.051 & $\mathbf{- 0 . 3 2 2}$ & -0.092 \\
CP Sc & $\mathbf{0 . 1 1 8}$ & -0.085 & $\mathbf{0 . 9 5 3}$ \\
LP Sc & $<0.001$ & $<0.001$ & $<-0.001$ \\
L-B Sc & $<-0.001$ & $<-0.001$ & $<0.001$ \\
DFR & $<-0.001$ & $<-0.001$ & $<0.001$ \\
AFR & 0.000 & 0.000 & 0.000 \\
PecFR & 0.092 & $\mathbf{0 . 9 0 4}$ & 0.090 \\
PelFR & 0.024 & $\mathbf{0 . 2 5 4}$ & $\mathbf{- 0 . 1 8 5}$ \\
\hline
\end{tabular}

